\section{Ankara Üniversitesi Eğitim Bilimleri \\ Fakültesi Özel Eğitim Dergisi}

2021, 22(4), 999-1024
DERLEME

Gönderim Tarihi: 28.02 .20

Kabul Tarihi: 15.11 .20

Erken Görünüm: 29.11.20

\title{
Öğrenme Güçlüğü ve Özel Yeteneği Olan İki Kere Farklı Bireylere Yönelik Yapılan Çalışmaların Gözden Geçirilmesi
}

\author{
Büşra Yılmaz-Yenioğlu iD 1
}

\author{
Macid Ayhan Melekoğlu iD 2
}

\section{Öz}

Giriş: İki kere farklı (2f; twice exceptional [2e]) kavramı; bireylerin bir ya da birden fazla alanda özel yetenek gösterirken bir ya da birden fazla alanda yetersizlik göstermesi ya da bu alanlarda güçlük yaşaması olarak açıklanmaktadır. $2 \mathrm{f}$ terimi; özel yeteneğinin yanı sıra özel öğrenme güçlüğü, dikkat eksikliği ve hiperaktivite bozukluğu, otizm spektrum bozukluğu veya sosyal duygusal gelişim bozukluğu gibi durumlardan birine de sahip olmayı içermektedir.

Yöntem: Bu araştırmanın amacı, özel yetenek ve öğrenme güçlüğü tanısı almış $2 \mathrm{f}$ bireylere yönelik 2014-2019 yılları arasında yapılan ulusal ve uluslararası çalışmaları inceleyerek betimsel analiz yapmaktır. Belirlenen anahtar kelimeler veri tabanlarında taranmış ve toplam 41 makale araştırma kapsamında incelenmiştir.

Bulgular: Araştırmanın sonucunda, 2f bireylere yönelik çalışma sayısının az olması nedeniyle tam olarak tanımlanamadıkları ve daha fazla sayıda çalışmaya ihtiyaç olduğu vurgulanmaktadır. Ayrıca incelenen makalelerin büyük çoğunluğunun betimsel araştırma olarak gerçekleştirildiği ve müdahale araştırmalarının sayısının oldukça sınırlı olduğu dikkat çekmektedir.

Tartı̧̧ma: Bulgular tartışılarak araştırma kapsamında incelenen makaleler hakkında genel bakış oluşturulmuştur. Anahtar sözcükler: İki kere farklı, 2f, özel öğrenme güçlüğü, özel yetenek, betimsel analiz.

Atıf için: Yılmaz-Yenioğlu, B., \& Melekoğlu, M. A. (2021). Öğrenme güçlüğü ve özel yeteneği olan iki kere farklı bireylere yönelik yapılan çalışmaların gözden geçirilmesi. Ankara Üniversitesi Ĕ̈itim Bilimleri Fakültesi Özel Ĕ̈itim Dergisi, 22(4), 999-1024. https://doi.org/10.21565/ozelegitimdergisi.696065

\footnotetext{
${ }^{1}$ Sorumlu Yazar: Araş. Gör., Ankara Üniversitesi, E-posta: byyenioglu @ ankara.edu.tr, https://orcid.org/0000-0002-5150-5944

${ }^{2}$ Prof. Dr., Eskişehir Osmangazi Üniversitesi, E-posta: macidayhan@ gmail.com, https://orcid.org/0000-0002-9933-5331
} 


\section{Giriş}

İki kere farklı (2f; twice exceptional [2e]) kavramı; bireylerin bir ya da birden fazla alanda özel yetenek gösterirken bir ya da birden fazla alanda yetersizlik göstermesi ya da bu alanlarda güçlük yaşaması olarak açıklanmaktadır (Neihart, 2008; Ömür, 2019). 2f kavramı ilk olarak 1970'li yılların sonlarına doğru gündeme gelmiştir ve günümüzde bu kavramla ilgili farkındalık artarak ilerlemeye devam etmektedir (Neihart, 2008; Sansom, 2015). Alanyazın incelendiğinde $2 \mathrm{f}$ bireylerden ilk olarak 1977 yılında yayınlanan "Providing Programs for the Gifted Handicapped (Özel Yetenekli Engelli Bireylere Program Sağlama)" kitabında bahsedildiği görülmektedir (Assouline \& Whiteman, 2011). Bu bireylere yönelik gerçekleştirilen ilk çalışmalar resmi olarak 1981 y1lında John Hopkins Üniversitesi tarafından başlatılımışır (Buică-Belciu \& Popovici, 2014). 2f terimini alanyazında ilk defa 2004 yılında James J. Gallegher kullanmıştır (Boothe, 2010).

$2 \mathrm{f}$ terimi; özel yeteneğinin yanı sıra özel öğrenme güçlüğü, dikkat eksikliği ve hiperaktivite bozukluğu (DEHB), otizm spektrum bozukluğu (OSB), sosyal duygusal gelişim bozukluğu, dil konuşma bozukluğu gibi durumlardan birine de sahip olmay1 içermektedir (Neihart, 2008; Ömür, 2019). Hem özel yetenekli hem de DEHB olan $2 \mathrm{f}$ bireyler, bir konuya dikkat verdiklerinde başka bir konuya geçmekte zorluk yaşama, zamansız hareket etme ve konuşma, rutinlerden sıkılma ve reddetme, topluma uyum sağlayamama ve inatçllık gösterme, çalışan belleği yeterince kullanamama, daha az sistematik düşünme gibi özellikler sergileyebilmektedir (Kaplan-Sayı, 2018; Karg1 \& Akman, 2003; Webb \& Latimer, 1993). Hem özel yetenekli hem de OSB olan 2f bireyler; üstün kelime dağarcığına sahip olmalarına rağmen sınılı iletişim kurma, sınırlı göz kontağı kurma, düşük sosyal iletişim kurma, yoğun ilgi alanlarına rağmen tek taraflı konuşma gibi özellikler gösterebilmektedir (Neihart \& Poon, 2009; Ömür, 2019). Hem özel yetenekli hem de sosyal duygusal gelişim bozukluğu olan $2 \mathrm{f}$ bireyler; güçlü gözlem yeteneğine rağmen hatıllamada zorluk yaşama, bilişsel zorluklarla karşılaşma, uzun süreli dikkatini vermede zorluk yaşama, risk almaktan kaçma, akranları tarafindan kabullenilmekte zorluk yaşama, inatçılık ve liderlik özellikleri sergileme, akranlarıyla ilişki kurmada güçlük yaşama gibi özellikler gösterebilmektedir (Gök vd., 2018). Hem özel yetenekli hem de özel öğrenme güçlüğü olan 2 f bireyler; ortalamanın üzerinde sözcük dağarcığına sahip olma, üretken hayal gücüne sahip olma, görsel ve uzamsal ilişkileri çabuk kavrama, okuma ve yazma becerilerinde güçlük yaşama, okuduğunu anlama becerilerinde güçlük yaşama, yönergeleri yerine getirmede güçlük yaşama, uzun ve kısa süreli bellekte sorunlar yaşama gibi özellikler sergileyebilmektedir (Buică-Belciu \& Popovici, 2014; İlker, 2017; Macfarlane, 2000; Sansom, 2015).

2f kavramına yönelik alanyazın, özel eğitim alanında oldukça yeni olmakla birlikte, çoğunlukla $2 \mathrm{f}$ bireyleri tanımlamakta, bu bireylerin akademik ve sosyal-duygusal gelişim özellikleri hakkında bilgi vermekte ve bu bireylerin kullandığı başa çıkma stratejilerini içermektedir (Neihart, 2008). İki kere farklı kavramını içeren alanyazında araştırmaların büyük çoğunluğu hem özel yeteneği hem de özel öğrenme güçlüğü olan $2 \mathrm{f}$ bireyler üzerinedir (Baum \& Owen, 1988; Cooper vd., 2004; Ferri vd., 1997; Fox vd., 1983; Moon \& Reis, 2004; Nielsen, 2002; Nielsen vd., 1994; Reis vd., 2000; Shaywitz vd., 2001; Vespi \& Yewchuck, 1992; Whitmore \& Maker, 1985). Duygusal bozuklukları veya fiziksel yetersizlikleri olan özel yetenekli bireylerle ilgili araştırma sayısı oldukça sınırlıdır (Baker, 1995; Eason vd.,1978; Gust-Brey \& Cross, 1999; Jackson, 1998; Morrison, 2001; Neihart, 2008; Willard-Holt, 1998). Son yıllarda özellikle DEHB ve OSB olan üstün yetenekli bireylerle ilgili gerçekleştirilen çalışmaların sayısında artış olduğu görülmektedir (Baum vd.,1998; Gök vd., 2018; Kaufmann vd., 2000; Moon vd., 2001; Morrison, 2001; Ömür, 2019; Zentall vd., 2001).

Özel eğitim kapsamında özel öğrenme güçlüğü, sık rastlanılan yetersizlikler kategorisinde yer almaktadır (Melekoğlu vd., 2009). Özel öğrenme güçlüğü olan bireylerin en önemli özellikleri normal ve normalüstü zekâ kapasitesine sahip olmaları fakat akademik alanlarda, özellikle okuma ve yazma alanlarında, anlamlı derecede güçlük yaşamalarıdır (İlker \& Melekoğlu, 2017). Özel öğrenme güçlüğü olan öğrencilerin bazıları aynı zamanda özel yetenekli bireyler olarak karşımıza çıkabilmektedir. Bu bireyler, okuma, yazma ve matematik dışında yer alan akademik beceriler, liderlik, yaratıcılık, görsel sanatlar gibi alanların bir ya da birden fazlasında özel yetenekli olarak tanımlanırken, okuma, yazma ve matematik gibi belirli alanların bir ya da birden fazlasında güçlük yaşayan bireyler olarak tanımlanmaktadır (Boothe, 2010). 2f bireyler yaygın olarak öğrenme güçlüğü ve özel yetenek gösteren öğrenciler olarak bilinmektedir (Buică-Belciu \& Popovici, 2014; Neihart, 2008; Nielsen, 2002). Bu bireyler için genel özelliklerden bahsetmek oldukça güçtür çünkü her bir birey, kişisel özellikleri açısından farkl11ıklar göstermektedir (Buică-Belciu \& Popovici, 2014; Foley-Nicpon, 2013; Nielsen, 2002).

2f bireylerin bazıları hem öğrenme güçlüğü hem de özel yetenek sergiledikleri için fark edilmeleri zor olabilmektedir. Bu öğrencilerin bazı durumlarda öğrenme güçlükleri özel yeteneklerini gölgeleyebileceği gibi bazı durumlarda da özel yetenekleri öğrenme güçlüklerinin önüne geçebilmektedir (Boothe, 2010; Trail, 2011). Tipik 
olarak özel yetenek ve öğrenme güçlüğü tanısı alan 2f bireyler aşağıda belirtilen üç kategoriden birinde yer almaktadır (Amran \& Majid, 2019; Buică-Belciu \& Popovici, 2014):

Özel yetenekli olarak tanılanan bireylere öğrenme güçlüğ̈̈ tanısı konulmaz. Bu grupta yer alan $2 \mathrm{f}$ bireylerin yetersizlikleri bireyin özel yetenekleri tarafindan maskelenir. İlkokulda başarılıdırlar ve özel yetenek programından faydalanabilmektedirler. Ancak beklenti ve sorumluluk arttıkça problem yaşayabilmektedirler. Zayıf benlik kavramı, motivasyon eksikliği veya tembel olarak görülmeleri nedeniyle genellikle başarısız olarak kabul edilirler (İlker, 2017). Öğrenme güçlüğü olarak tanılanan bireylere özel yetenek tanısı konulmaz. Bu grupta yer alan $2 \mathrm{f}$ bireylerin özel yetenekleri yetersizlikleri ile gölgelenir. Bu bireyler, potansiyelleri fark edilmedikleri için nadiren özel yetenek tanısı alır ve bu hizmetlere yönlendirilir. Hem ögrenme güçlüğ̈̈ hem de özel yetenek tanısı konulmaz. Bu grupta yer alan $2 \mathrm{f}$ bireyler ortalama olarak kabul edilir. Bu yüzden ne yetersiz ne de özel yetenekli olarak fark edilirler. Bu bireylerin genellikle zekâ puanları ve performansları arasında farklılık gözlenmez. Bu grupta yer alan bireylerin öğrenme güçlüğü ile özel yeteneği birbirini gölgeler (Amran \& Majid, 2019; Buică-Belciu \& Popovici, 2014).

2f bireylerin tanılanmasında açık tanı ölçütlerinin bulunmaması, yeterli standart değerlendirme araçlarının bulunmaması ve bu bireylerin özellikleri ile ilgili birçok belirsizliğin olması nedeniyle bu bireyleri tanılamakta yetersiz kalınmaktadır. 2f bireylerin hem yetenekleri hem de gereksinimleri zamanla değiştiği için bu bireyleri tanılamanın okul yıllarında devam eden bir süreç olması gerektiği vurgulanmaktadır (Brody \& Mills, 1997). Ancak özel yeteneği ve öğrenme güçlüğü olan 2f bireylerin kesin olarak tanılanması ve gereksinimleri doğrultusunda eğitim alması özel eğitim alanında önemli fakat belirsiz bir durum olmaya devam etmektedir. Tanılanma sürecindeki belirsizliklerin giderilebilmesi için $2 \mathrm{f}$ bireylerin özelliklerinin iyi analiz edilmesi oldukça önemlidir (Buică-Belciu \& Popovici, 2014; Krochak \& Ryan, 2007; Newman \& Sternberg, 2004; Silverman, 2009).

Özel yeteneği ve öğrenme güçlüğü olan $2 \mathrm{f}$ bireyler; üretken, hayal gücü geniş, belirli alanlarda uzmanlaşmış, ilgi alanları farklılaşan ve öğrenme güçlüğü yaşamalarına rağmen fen bilimleri ve geometri gibi alanlarda üstün performans gösterebilen bireyler olarak görülmektedir (İlker, 2017; Macfarlane, 2000; Stewart, 2003). Bunlara ek olarak $2 \mathrm{f}$ bireyler, görsel ve işitsel olarak çabuk anlayan, üstbilişsel becerileri, akıl yürütme ve problem çözme becerileri iyi olan bireyler olarak tanımlanmaktadır (Buică-Belciu \& Popovici, 2014; Stewart, 2003). $2 \mathrm{f}$ bireylerin tüm bu güçlü yönlerinin yanı sıra bazı zayıf yönleri de bulunmaktadır (Sansom, 2015). Bu bireyler çoğunlukla sınıf ortalamasının altında performans gösterdikleri için sınıf içinde yapılan etkinliklere katılmayı tercih etmeyebilmektedir. Kısa ve uzun süreli bellekte sorun yaşamakta, yönerge takibi yapamamakta, okuma ve yazma hataları sergilemekte ve okuduğunu anlamada zorluk yaşamaktadırlar (Baldwin, Baum, vd., 2015; Foley-Nicpon, 2015; Nielsen, 2002). Akademik alanların yanı sıra bu bireyler sosyal duygusal alanda da bazı sorunlar yaşayabilmektedir. Kendilerinden beklenen yüksek performansı göstermeme durumunda öfkelenebilmekte ve okula karşı nefret duygusu geliştirebilmektedirler (Buică-Belciu \& Popovici, 2014; İlker, 2017). Öğrenilmiş çaresizlik yaşadıkları için motivasyonları düşük olabilmekte ve akranlarıyla iletişim kurmada zorlanabilmektedirler (Sansom, 2015). Bunun yanı sıra başarısızlık yaşadıkları durumlarda başkalarını bu başarısızlıklarından sorumlu tutabilmektedirler (Buică-Belciu \& Popovici, 2014; Macfarlane, 2000; Sansom, 2015).

Amran ve Majid (2019) tarafından gerçekleştirilen bir araştırmada, 2f bireylere yönelik kullanılan öğrenme stratejilerini, müdahaleleri ve uygulamaları içeren araştırmalara yönelik bir alanyazın taraması gerçekleştirilmiştir. Yazarlar, 2000-2018 yılları arasında bu bireylere yönelik müdahalelerin gerçekleştirildiği 44 araştırmayı incelemiş ve özetlemiştir. Araşsırma sonucunda yazarlar, etkili müdahalenin gerçekleştirilebilmesi için 2f bireylerin güçlü yanlarına odaklanmak gerektiğini ve bu bireylerin öğretmen, aile ve akranlarının da desteklerine ihtiyaç duyduklarını belirtmektedir.

Türkiye'de özel yetenek ve öğrenme güçlügü tanısı alan $2 \mathrm{f}$ bireylere yönelik bir makaleye rastlanılmamakla birlikte özel yeteneğine ek DEHB ve OSB tanısı almış bireylerle gerçekleştirilen çalışmalarla ilgili iki makale ve bir teze ulaşılmıştır. Kargı ve Akman (2003) yaptıkları araştırmada, özel yetenekli ve DEHB olan $2 \mathrm{f}$ bireylerin akademik, sosyal-duygusal gelişim özelliklerini ortaya koymuştur. Araştırma sonucunda yazarlar, $2 \mathrm{f}$ bireylerin özelliklerinin iyi bilinmesini, zayıf ve güçlü yönlerinin belirlenmesini ve bu bireylerin gereksinimleri doğrultusunda eğitim ortamlarının oluşturulması gerektiğini vurgulamaktadır. Kaplan-Sayı (2018) araştırmasında, üstün zekâ ve DEHB kavramlarını açıklayarak; üstün zekâlı ve DEHB'e sahip olma durumunu netleştirerek alanyazına katkıda bulunmayı amaçlamıştır. Bu amaç doğrultusunda bu bireylerin akademik ve sosyal-duygusal özelliklerini açılayarak üstün zekâlı ve DEHB'i olan iki kere farklı çocukların özellikleri ve 
tanılanmalarına yönelik öneriler sunmuştur. Ömür (2019) yaptı̆̆ı araştırmada, özel yetenekli ve OSB olan 2f çocukların özelliklerini ve davranışlarını ortaya koyarak, bu çocukların tanı ölçütlerine katkı sağlayabileceği özellikleri, davranışları ve gereksinimlerini içeren bir model oluşturmayı amaçlamıştır. Bu amaç doğrultusunda yazar, $2 \mathrm{f}$ olan üç çocuk ve ebeveynlerinden veri toplamıştır. Araştırma sonucunda, $2 \mathrm{f}$ çocukların tanı karmaşası yaşadığı, davranışlarının ve özelliklerinin anlaşılmadığı, bilişsel profillerinin önemsenmediği ve bilişsel isteklerinin karşılanmadığı ortaya konmuştur.

2f bireyler, özel eğitim alanı içinde oldukça yeni bir grup olarak tanımlanmaktadır. Bu nedenle bu bireylerin özelliklerinin bilinmesi ve bu bireylere gereksinimleri doğrultusunda eğitim verilmesinin gerektiği vurgulanmaktadır. Bu bireylere yönelik gerçekleştirilen araştırmaların sayısının hem ulusal hem de uluslararası alanyazında sınırlı olması ve özel yeteneği ve özel öğrenme güçlüğü olan $2 \mathrm{f}$ bireylere yönelik Türkiye'de bir makaleye rastlanılamaması nedeniyle bu araştırmanın yapılmasına gereksinim duyulmuştur. $\mathrm{Bu}$ araştırmanın amacı, özel yeteneği ve özel öğrenme güçlüğü olan 2 f bireylere yönelik 2014-2019 yılları arasında yapılan ulusal ve uluslararası güncel çalışmaları incelemek ve bu çalışmaları farklı özellikleri açılarından değerlendirmektir. İncelenen çalışmalar doğrultusunda elde edilen sonuçlar ile yapılan çalışmalara genel bir bakış sağlanmış, gelecekte bu konuya yönelik yapılacak çalışmalar konusunda tartışmaya yer verilmiş ve öneriler sunulmuştur. $\mathrm{Bu}$ makalede $2 \mathrm{f}$ terimi özel yeteneği ve öğrenme güçlüğü olan bireyler için kullanılmıştır.

\section{Yöntem}

\section{Araştırma Modeli}

$\mathrm{Bu}$ araştırma, özel yetenek ve öğrenme güçlüğü tanısı almış 2f bireylere yönelik yapılan çalışmaların gözden geçirilmesinin amaçlandığı nitel bir araştırmadır. Bu araştırma kapsamında doküman analizi yöntemi kullanılmış olup veriler elektronik dokümanlardan elde edilmiş ve verilerin analizinde betimsel analiz tekniği kullanılmıştır. Araştırmada yer alacak makalelerin taranması sürecinde araştırmanın amacı doğrultusunda veri toplama kaynağı olarak, internet üzerinden elektronik veri tabanları taranmıştır.

\section{Tarama Süreci}

Tarama sürecinde ilk olarak "iki kere farklı", "özel yetenek ve öğrenme güçlüğü” ve "üstün zekâ ve öğrenme güçlüğ̈̈" anahtar kelimeleri kullanılarak Türkiye Bilimsel ve Teknolojik Araştırma Kurumu Ulusal Akademik A $\breve{g}$ ve Bilgi Merkezi (TÜBİTAK ULAKBİM) veri tabanı ve DergiPark sistemi taranmıştır. Bu tarama sonucunda Türkiye'de yayınlanmış bir makaleye ulașıılmıștır. Ancak bu makalede $2 \mathrm{f}$ terimi özel yetenek ve dikkat eksikliği/hiperaktivite bozukluğunun birlikte görüldüğü bir durum için kullanıldığından bu makale, araştırma kapsamına dâhil edilmemiştir (Kaplan-Sayı, 2018). Ardından "twice exceptional", "gifted with learning disabilities" ve "twice exceptional students" anahtar kelimeleri kullanılarak SAGE, Proquest ve EbscoHost veri tabanlarında elektronik tarama yapılmıştır. SAGE veri tabanında "twice exceptional" anahtar kelimesi ile 172 makale, "gifted with learning disabilities" anahtar kelimesi ile üç ve "twice exceptional students" anahtar kelimesi ile 86 makaleye ulaşılmıştır. Proquest veri tabanında "twice exceptional" anahtar kelimesi ile 142 makale, "gifted with learning disabilities" anahtar kelimesi ile 14 ve "twice exceptional students" anahtar kelimesi ile 71 makaleye ulaşılmıştır. EbscoHost veri tabanında "twice exceptional" anahtar kelimesi ile 146 makale, "gifted with learning disabilities" anahtar kelimesi ile bir ve "twice exceptional students" anahtar kelimesi ile 22 makaleye ulaşılmıştır.

\section{Dâhil Etme ve Dışlama Ölçütleri}

Makalelerin araştırma kapsamında incelenebilmesi için dâhil etme ve dışlanma ölçütleri belirlenmiştir. Makalelerin dâhil etme kapsamında belirlenen ölçütler şu şekilde sıralanmaktadır; (a) araştırmaların 2014-2019 yılları arasında yapılmış olması, (b) araştırmada yer alan 2f bireylerin öğrenme güçlüğü ve özel yetenek tanısı almış olması, (c) araştırmanın hakemli bir dergide yayımlanmış makale olmasıdır. Makalelerin dışlanmasında belirlenen ölçütler ise şunlardır; (a) araştırmanın 2014 yılı öncesinde yayınlanmıș olması, (b) araștırmada yer alan $2 \mathrm{f}$ bireylerin öğrenme güçlüğü dışında tanı almış olmasıdır. Tarama sonucunda elde edilen makaleler dâhil etme ve dışlama ölçütlerine göre incelenmiş ve 41 makalenin araştırma kapsamında belirlenen dâhil etme ölçütlerine sahip olduğu belirlenmiştir. Elde edilen makalelere genel bir bakış oluşturabilmek amacıyla makalelerin ilk olarak; (a) ulusal ve uluslarası alanyazına göre dağılımı, (b) ülkelere göre dağılımı, (c) yıllara göre dağılımı ve (d) araştırma türlerine göre dağılımı incelenmiştir. Ardından makaleler, araştırmanın amacı, yöntemi, katılımcı özellikleri ve veri toplama araçları değişkenleri açısından analiz edilmiştir.

Makaleler analiz edilirken ilk olarak numaralandırılmıştır. Ardından araştırmacılar, makaleleri inceleyerek araştırma yöntemlerine göre üç kategori belirlemiştir. Bunlar; (a) $2 \mathrm{f}$ bireylere yönelik gerçekleştirilen 
betimsel araştırmalar, (b) $2 \mathrm{f}$ bireylere yönelik gerçekleştirilen karşılaştırma araştırmaları ve (c) $2 \mathrm{f}$ bireylere yönelik gerçekleştirilen müdahale araştırmalarıdır. Betimsel araştırmalar da kendi içinde üç gruba ayrılmıştır. Bunlar; $2 \mathrm{f}$ bireylerin kişisel ve öğrenme özellikleri hakkında bilgi veren araştırmalar, $2 \mathrm{f}$ olan bireyler hakkında ebeveynlerden, öğretmenlerden, yöneticilerden ya da bireylerin kendisinden görüş alan araştırmalar ve $2 \mathrm{f}$ bireylere yönelik alanyazın taraması yapılan araştırmalardır. Numaralandırılan makaleler, belirlenen kategorilerden uygun olana yerleştirilmiştir. Makalelerin kısa analizleri tablo içinde verilmiştir. Ayrıca buna ek olarak, makalelerin farklı ya da benzer yönlerine ilişkin bulgular verilerek makaleler karşılaştırmalı olarak incelenmiştir.

\section{Güvenirlik}

Tarama güvenirliğini sağlamak amacıyla özel eğitim alanında bir uzmandan aynı anahtar kelimeleri kullanarak yukarıda belirtilen veri tabanlarında elektronik tarama yapması istenmiş̧ir. Yapılan tarama sonucunda araştırmacılar tarafindan ulaşılan makalelerin aynılarına ulaşılmışıı. Kodlayıcı güvenirliği \%100 olarak hesaplanmıștır. Makaleler kategorilere yerleștirilirken ilk olarak yazarlar birbirinden bağımsız șekilde makaleleri okumuş ve makaleleri kategorilere yerleştirmişlerdir. Makaleleri kategorilere yerleştirmede yazarlar arası \%95 tutarlılık sağlanmıştır. Ardından bir araya gelerek belirlenen kategoriler üzerinde tartışarak makaleleri kategorilere yerleştirmede ortak bir sonuca ulaşmışlardır. Şekil 1'de tarama sürecinde yer alan aşamalar gösterilmektedir.

\section{Şekil 1}

Tarama Süreci Aşamaları

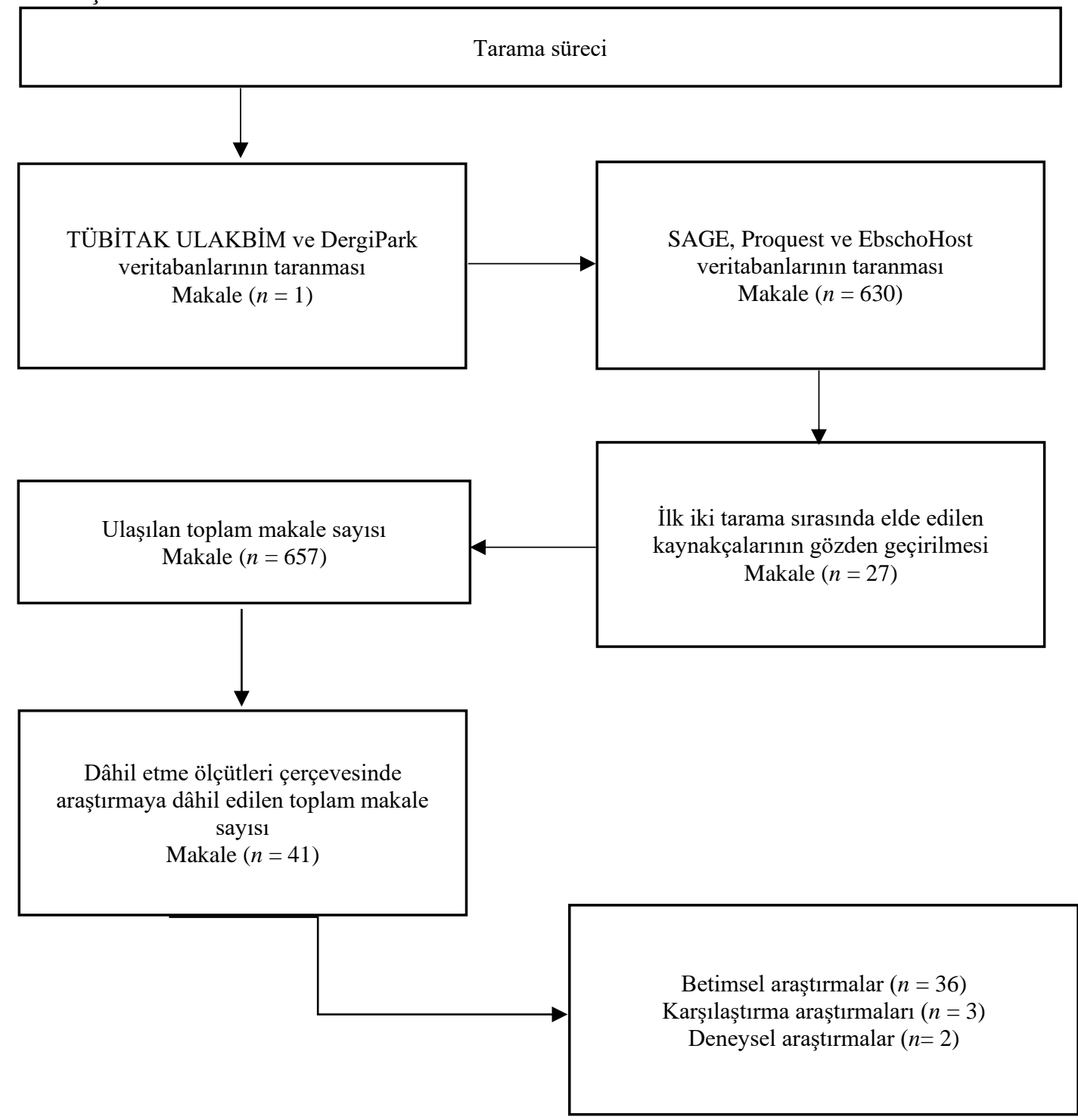




\section{Bulgular}

$\mathrm{Bu}$ çalışmanın amacı, ulusal ve uluslararası alanyazında özel yetenek ve öğrenme güçlüğü olan $2 \mathrm{f}$ bireylere yönelik 2014-2019 yılları arasında yapılmış çalışmaları içeren makaleleri incelemektir. Bu amaç doğrultusunda yazarlar her bir kategoriye ait makaleleri tabloya yerleştirerek özetlemiştir. Makalelere ilişkin özet bilgiler Şekil 2-5'te verilmiştir. Araştırma kapsamında ele alınan makalelerin ulusal ve uluslararası alanyazında yer alma durumu Şekil 2'de gösterilmektedir. Bu bulguya göre araştırma kapsamında ele alınan çalışmaların tamamının yurtdışında yapıldığı görülmektedir.

\section{Şekil 2}

$2 f$ Bireylere Yönelik Yapılan Çalışmaların Ulusal ve Uluslararası Alanyazına Göre Dağılımı

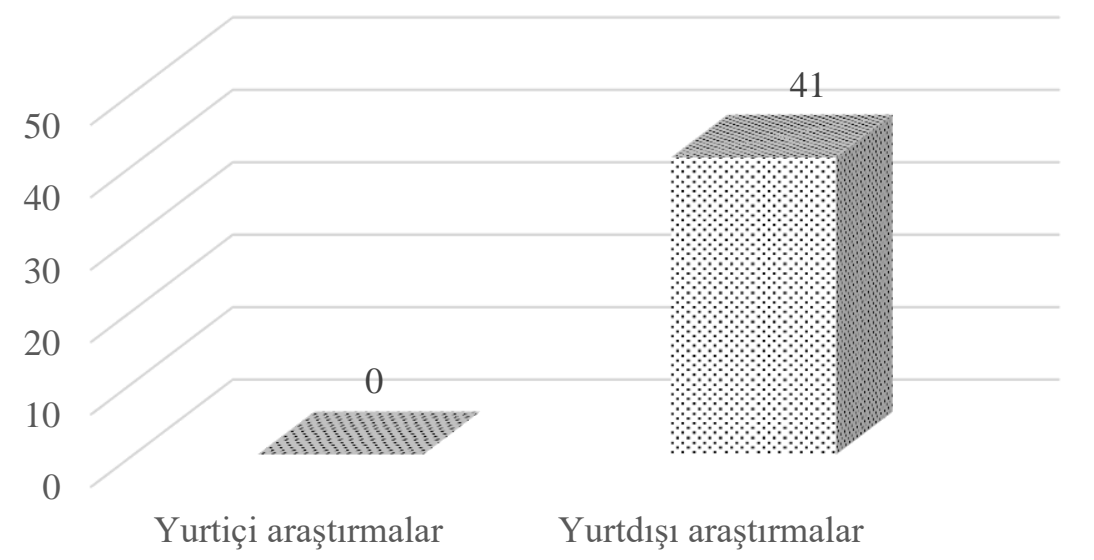

Bu çalışma kapsamında ele alınan makalelerin gerçekleştirildiği ülkelere göre dağılımı Şekil 3’te gösterilmektedir. Konuyla ilgili yapılan çalışmalar 13 farklı ülkede gerçekleştirilmiştir. Ancak yapılan çalışmaların büyük çoğunluğunun Amerika Birleşik Devletleri (ABD)'de gerçekleştirildiği görülmektedir.

\section{Şekil 3}

2 f Bireylere Yönelik Yapılan Çalışmaların Ülkelere Göre Dă̆glımı

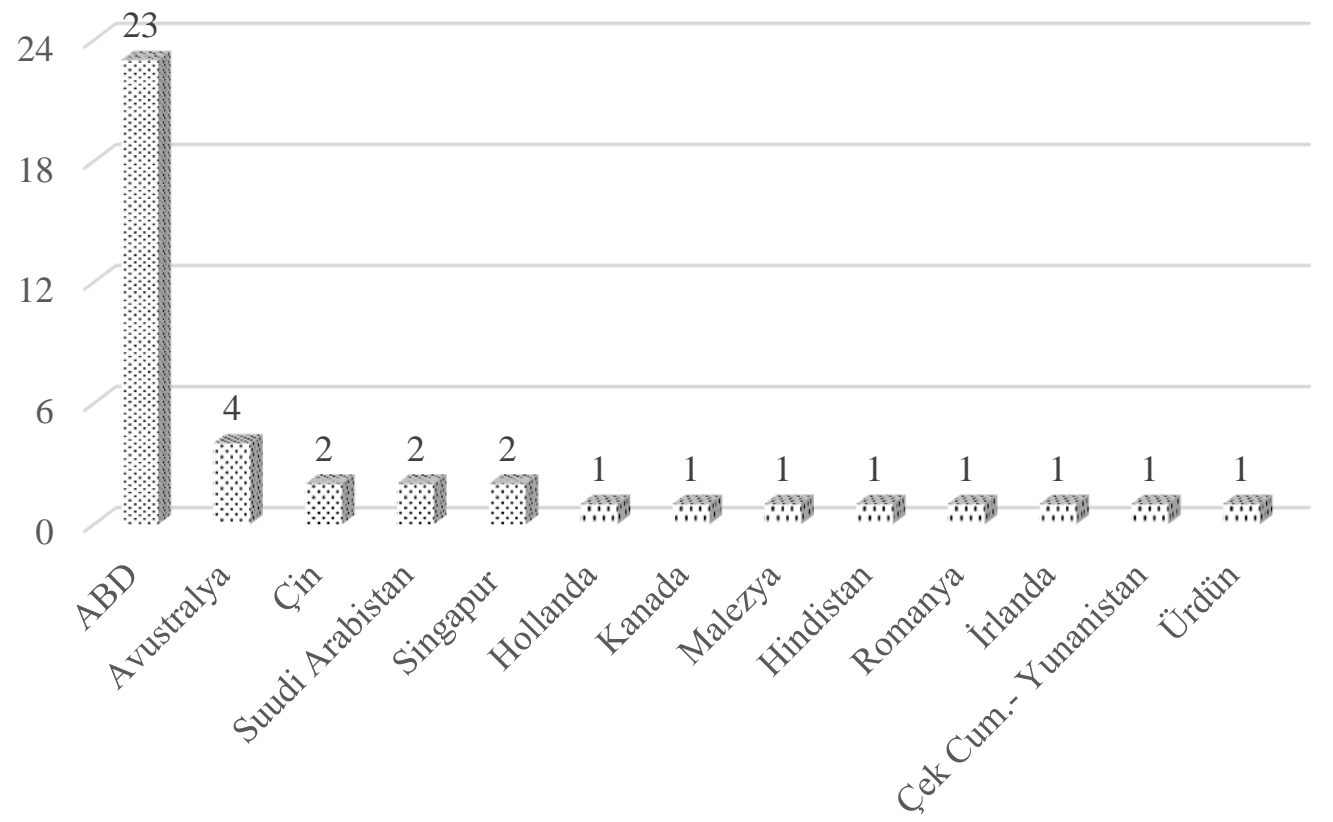

$\mathrm{Bu}$ çalışma kapsamında ele alınan makalelerin yayınlandığı yıllara göre dağılımı Şekil 4'te gösterilmektedir. Elde edilen sonuçlara göre makalelerin sayısının en yüksek olduğu yılın 2015 ve en düşük olduğu 
yılın ise 2017 olduğu görülmektedir. Ayrıca incelenen yılların her birinde konuyla ilgili en az iki makale yayınlandığı görülmektedir.

\section{Şekil 4}

2f Bireylere Yönelik Yapılan Çalışmaların Makalelerinin Yayınlanma Yıllarına Göre Dağılımı

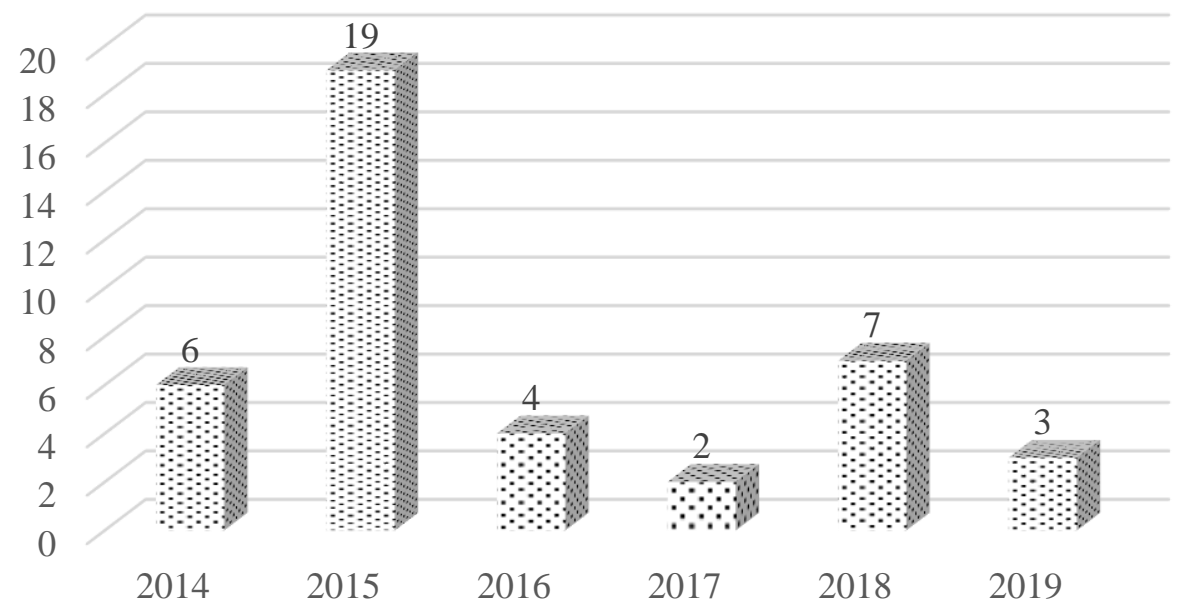

$\mathrm{Bu}$ çalışma kapsamında ele alınan makalelerin araștırma türlerine göre dağılımı Şekil 5'te gösterilmektedir. Elde edilen sonuçlara göre makalelerin büyük çoğunluğu bilgi vermeyi ve var olan durumu ortaya koymayı amaçlayan betimsel araştırmalardır. Betimsel araştırmalara ek olarak karşılaştırma ve müdahale araştırmaları da yer almaktadır.

\section{Şekil 5}

2f Bireylere Yönelik Yapılan Çalışmaların Araştırma Türlerine Göre Dă̆ılım

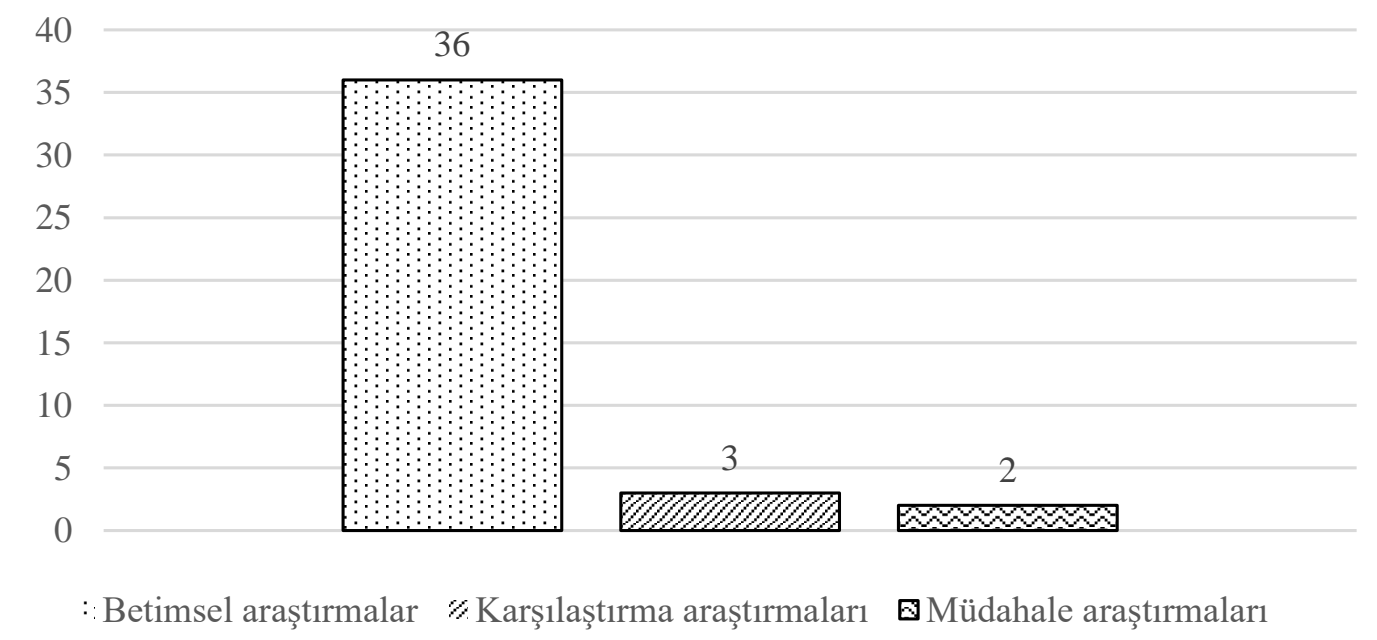

\section{2f Bireylere Yönelik Yapılan Betimsel Araştırmalar}

$\mathrm{Bu}$ araştırmada ele alınan betimsel araştırmalar, (a) $2 \mathrm{f}$ bireylerin kişisel ve öğrenme özellikleri hakkında bilgi veren araştırmalar, (b) $2 \mathrm{f}$ bireyler hakkında ebeveynlerden, öğretmenlerden, yöneticilerden ya da bireylerin kendisinden görüş alan araştırmalar, (c) $2 \mathrm{f}$ bireylere yönelik alanyazın taraması yapılan araştırmalar olarak kategorilendirilmiştir.

\section{2f Bireylerin Kişisel ve Öğrenme Özellikleri Hakkında Bilgi Veren Araştırmalar}

2f bireylerin kişisel özellikleri, öğrenme özellikleri ve bu bireylere yönelik öğrenme stratejileri hakkında bilgi veren ve bu stratejilerin nasıl uygulanması gerektiğine dair açıklamalar yapan ve bu bireylere yönelik devlet 
politikalarını ve yasal hakları açıklayan araştırmalar bu kategoride yer almıştır. Toplam 19 çalışma bu kategoriye dâhil edilmiştir. Bu araştırmalara ilişkin bulgular Tablo 1'de yer almaktadır.

\section{Tablo 1}

2f Bireylerin Kişisel ve Öğrenme Özellikleri Hakkında Bilgi Veren Araştırmalar

\begin{tabular}{ll}
\hline \multicolumn{1}{c}{ Kaynak } & \multicolumn{1}{c}{ Araştırmanın amacı } \\
\hline $\begin{array}{l}\text { Popovică-Belciu \& } \\
\text { 2014 }\end{array}$ & $\begin{array}{l}\text { 2f olan bireylerin tanımlanmas1 ve } \\
\text { müdahale stratejilerinin } \\
\text { belirlenmesi }\end{array}$ \\
Reis vd., 2014 & 2f kavramını yeniden tanımlamak \\
Yssel vd., 2014 & $\begin{array}{l}\text { 2f olan öğrencilere yönelik } \\
\text { uygulanan müdahaleye tepki } \\
\text { modeli hakkında bilgi vermek }\end{array}$ \\
& $\begin{array}{l}\text { Müzik dersi kapsamında 2f olan } \\
\text { öğrencilerin özelliklerini } \\
\text { tanımlamak }\end{array}$ \\
Abramo, 2015
\end{tabular}

Baldwin,

Baum, vd., 2015

Foley-Nicpon \& Assouline, 2015

Baldwin,

Omdal, vd., 2015

Ronksley-

Pavia, 2015

Satterley, 2015 gözünden 2f öğrenciler hakkında

Amend \&

Peters, 2015

Foley-Nicpon, 2015 Foley-Nicpon
vd., 2015

Barnard-Brak vd., 2015
The 2f CoP Summit (The National Twice-Exceptional Community of Practice) hakkında bilgi vermek

2f olan öğrencilerle nas1 çalışılacağı hakkında bilgi vermek

2f ögrrencileri tanımlamak ve öğrenme özellikleri hakkında bilgi vermek

2f hakkında bir nokta oluşturarak gelecekteki araştırmaları temel olabilecek bir modelin oluşturulmasında katkıda bulunan faktörleri incelemek

Özel eğitim koordinatörü bilgi vermek

Klinik psikologların gözünden $2 \mathrm{f}$ öğrenciler hakkında bilgi vermek

Bir psikologun gözünden $2 \mathrm{f}$ öğrenciler hakkında bilgi vermek

Bulgular

açıklanmakta ve ortak müdahale stratejileri tartışılmaktadır.

Araştırma sonucunda yazarlar, 2f kavramı için farklı grupları da temsil edecek bir tanım sunmakta ve bu tanımın politika yapıcıları, profesyonelleri ve ebeveynleri daha fazla birlikte çalışmaya teşvik edeceğini vurgulamaktadır.

Araştırma sonucunda yazarlar, müdahaleye tepki modelinin $2 \mathrm{f}$ olan öğrencilerin erken dönemde tanılanması ve eğitim gereksinimlerinin belirlenmesi için önemli olduğunu vurgulamaktadır.

Araştırma sonucunda yazar, müzik dersinde $2 \mathrm{f}$ öğrencilere yönelik öğrenme stratejilerini açıklamakta, öğrencilere seçim esnekliği sağlanması gerektiğini belirtmekte ve özdenetim ve organizasyon becerilerinin geliştirilmesi gerektiğini vurgulamaktadır.

Araştırma sonucunda yazarlar, son 50 yıldır tartışılan $2 \mathrm{f}$ öğrencilerin eğitim gereksinimlerini karşılamak ve uygun ögrenme ortamları oluşturabilmek amacıyla kurulan The $2 \mathrm{f} \mathrm{CoP}$ Summit hakkında bilgiler vererek bu ögrencileri akademik anlamda ileriye taşımak için önerilerde bulunmuşlardır.

Araştırma sonucunda yazarlar, $2 \mathrm{f}$ olan bireylerle yaşamın her alanında karşılaşabileceğimizi, onlarla çalışırken ebeveynler ve eğitimcilerle iş birliği yapmamız gerektiğini ve onları her alanda desteklememiz gerektiğini belirtmektedir.

Araştırma sonucunda yazarlar, $2 \mathrm{f}$ öğrencileri tanımlamakta, kişisel ve öğrenme özelliklerini belirtmekte ve öğrenme ihtiyaçlarını belirterek öğrenme stratejilerini vurgulamaktadır.

Araştırma sonucunda yazar, bu alanda araştırma eksikliklerinin olduğunu, ortak bir fikir birliğinin olmadığını ve bu sebeple bu bireyleri tanımlamada, sınıflandırmada ve uygulamada eksiklik olduğu vurgulanmaktadır. Yazar, uygulama ve müdahaleleri kolaylaştırmak amacıyla bir model geliştirmiştir.

Araştırma sonucunda özel eğitim koordinatörü, $2 \mathrm{f}$ öğrencilerin güçlü ve zayıf yönlerinin belirlenmesi ve personeller arasında iş birliği yapılması gerektiğini vurgulamaktadır.

Araştırma sonucunda klinik psikologlar, 2 f öğrencileri tanılayıp sınıflandırmaktan ziyade onların zayıf ve güçlü olduğu yönlerin belirlenmesinin daha önemli olduğunu vurgulamaktadır.

Araştırma sonucunda psikolog, eğitimciler, ebeveynler ve psikologların 2f olan öğrencilerin bireysel farklılıklarını daha iyi anlamak için daha donanımlı olmaları gerektiğine ve onların başarılarına odaklanılması gerektiğini vurgulamaktadır.

2f olan bireylerin bilişsel yetenekleri ve eğitim hizmetlerine katılımı ile ilişskili olarak benlik kavramı profilini araştırmak

Araştırma sonucunda, $2 \mathrm{f}$ bireylerin benlik kavramı profillerinin ortalama aralıkta olduğu görülmekte ve bunun da üstün yetenek kısmının koruyucu bir mekanizma olarak kullanıldığ 1 belirtilmektedir.

Araştırma sonucunda yazarlar, son 20 yıldır 2 f olan öğrencilere yönelik farkındalık artmasına rağmen bu öğrencilerin risk altında olduğunu ve bu ögrencilere yönelik daha fazla araştırma yapılması gerektiğini vurgulamaktadır. 
Tablo 1 (devamı)

\begin{tabular}{|c|c|c|}
\hline Kaynak & Araştırmanın amacı & Bulgular \\
\hline $\begin{array}{l}\text { Mayes \& } \\
\text { Moore, 2016b }\end{array}$ & $\begin{array}{l}\text { Afrikan-Amerikalı olan } 2 \mathrm{f} \\
\text { ögrencilerde rrk, engellilik ve } \\
\text { özel yeteneğin kesişimini } \\
\text { incelemek }\end{array}$ & $\begin{array}{l}\text { Araştırma sonucunda yazar, Afrikan-Amerikalı olan } 2 \mathrm{f} \\
\text { ögrencilerin zorluklarla ve irkçılıkla karşılaşacağını } \\
\text { vurgulamaktadır. Ayrıca, ebeveynlerin eğitim ihtiyaçları } \\
\text { olduğunu ve hizmet içi eğitimlerin de yaygınlaşması gerektiğini } \\
\text { belirtmektedir. }\end{array}$ \\
\hline $\begin{array}{l}\text { Kurup \& Dixit, } \\
2016\end{array}$ & $\begin{array}{l}\text { 2f bireyler için Hindistan'da } \\
\text { yapılan uygulamalar hakkında } \\
\text { bilgi vermek }\end{array}$ & $\begin{array}{l}\text { Araştırmada genel olarak } 2 \mathrm{f} \text { bireylerin özellikleri ve öğretim } \\
\text { stratejileri hakkında bilgi verilmekte ve Hindistan'da bu bireyler } \\
\text { için tanılama ve müdahaleler olması gerektiği vurgulanmaktadır. }\end{array}$ \\
\hline $\begin{array}{l}\text { O'Sullivan vd., } \\
2017\end{array}$ & $\begin{array}{l}\text { Minecraft video oyunu ile } 2 \text { f olan } \\
\text { öğrencilerin öğrenme } \\
\text { ihtiyaçlarına yönelik öğrenme } \\
\text { ortamı oluşturmak }\end{array}$ & $\begin{array}{l}\text { Araştırma sonucunda yazarlar, } 2 \text { f olan öğrencilerin öğrenme } \\
\text { ihtiyaçlarını karşılamaya yönelik öğrenme ortamını Minecraft } \\
\text { video oyunu ile oluşturulabileceğini belirtmekte ve öneriler } \\
\text { sunmaktadır. }\end{array}$ \\
\hline $\begin{array}{l}\text { Maddocks, } \\
2018\end{array}$ & $\begin{array}{l}\text { 2f öğrencileri tanılamada } \\
\text { kullanılan aracı öğrencilere } \\
\text { uygulamak }\end{array}$ & $\begin{array}{l}\text { Araştırma sonucunda yazarlar, genel değerlendirme prosedürlerine } \\
\text { kıyasla öğrencilerin güçlü ve zayıf yönlerini aynı anda inceleyen } \\
\text { bireysel odaklı bir sürece ihtiyaç olduğunu vurgulamaktadır. }\end{array}$ \\
\hline $\begin{array}{l}\text { Lee \& } \\
\text { Ritchotte, } \\
2018\end{array}$ & $\begin{array}{l}\text { 2f bireylerin özelliklerini ve } \\
\text { ihtiyaçlarını karşılamak için } \\
\text { genel bilgi vermek }\end{array}$ & $\begin{array}{l}\text { Araştırmada, } 2 \text { f bireylerin yasal haklarını ve mesleki girişimlerini } \\
\text { desteklemek, eğitim haklarını tartışmak, bu bireyleri desteklemek } \\
\text { ve bu bireylere sürekli personel eğitimi konusunda bilgi } \\
\text { vermektedir. }\end{array}$ \\
\hline $\begin{array}{l}\text { Mohammed, } \\
2018\end{array}$ & $\begin{array}{l}\text { 2f olan bireylere yönelik Suudi } \\
\text { Arabistan'da yapılan devlet } \\
\text { politikalarının incelenmesi }\end{array}$ & $\begin{array}{l}\text { Araştırmada, 2f bireylerin yasal haklarına ilişkin bilgiler } \\
\text { verilmekte ve sonunda da Suudi Arabistan'da bu bireyler için } \\
\text { politika geliştirme, uygulayıcı eğitimi, hizmet müdahaleleri ve } \\
\text { değerlendirmeler için öneriler sunulmaktadır. }\end{array}$ \\
\hline
\end{tabular}

Not: Makaleler yayın yılına göre geçmişten günümüze doğru sıralanmıştır.

\section{2f Olan Bireyler Hakkında Ebeveynlerden, Öğretmenlerden, Yöneticilerden Ya Da Bireylerin Kendisinden Görüş Alan Araştırmalar}

2f olan bireyler hakkında ebeveynlerden, öğretmenlerden, yöneticilerden ya da bireylerin kendisinden görüş alan ve bu görüşler doğrultusunda bu bireylere yönelik önerilerde bulunan araştırmalar bu kategoride yer almıştır. Toplam 15 çalışma bu kategoriye dâhil edilmiştir. Bu araştırmalara ilişkin bulgular Tablo 2'de verilmektedir.

\section{2f Bireylere Yönelik Alanyazın Taraması Yapılan Araştırmalar}

2f olan bireylere yönelik araşırmaların yer aldığı alanyazın taramalarını içeren araştırmalar bu kategoride yer almıştır. Toplam iki çalışma bu kategoriye dâhil edilmiştir. Bu araştırmalara ilişkin bulgular Tablo 3 'te yer almaktadır.

2f Bireylere Yönelik Yapılan Karşılaştırma Araştırmaları. Bu araştırmada ele alınan $2 \mathrm{f}$ olan bireyleri, sadece öğrenme güçlüğü olan akranları, sadece özel yetenekli akranları ya da tipik gelişim gösteren akranları ile akademik ve gelişim özellikleri açısından karşılaştıran araştırmalar, bu kategoride yer almıştır. Toplam üç araştırma, bu kategoriye dâhil edilmiştir. Bu araştırmalara ilişsin bulgular Tablo 4'te verilmektedir.

2f Bireylere Yönelik Yapılan Müdahale Araştırmaları. Bu araştırmada ele alınan $2 \mathrm{f}$ bireylerin akademik başarılarını artırmak için bir müdahale yönteminin etkililiğinin incelendiği araştırmalar bu kategoride yer almıştır. Toplam iki araştırma bu kategoriye dâhil edilmiştir. Bu araştırmalara ilişkin bulgular Tablo 5 'te verilmektedir 
ÖĞRENME GÜÇLÜĞÜ VE ÖZEL YETENEĞİ OLAN IKİ KERE FARKLI BIREYLERE YÖNELIK YAPILAN ÇALIŞMALARIN GÖZDEN GEÇiRILMESI

Tablo 2

2 f Bireyler Hakkında Ebeveynlerden, Öğretmenlerden, Yöneticilerden ya da Bireylerin Kendisinden Görüş Alan Araştırmalar

\begin{tabular}{|c|c|c|c|c|c|}
\hline Kaynak & Araştırmanın amacı & Yöntem & Katılımc1lar ve özellikleri & Veri toplama araçları & Bulgular \\
\hline $\begin{array}{l}\text { Lo \& Yuen, } \\
2014\end{array}$ & $\begin{array}{l}2 \text { f olan öğrencilerin baş etme } \\
\text { stratejilerini araştırmak }\end{array}$ & Nitel & $\begin{array}{l}\text { 9. ve } 12 \text {. sinıfa giden } 2 \mathrm{f} \\
\text { olan } 3 \text { Çinli öğrenci }\end{array}$ & Görüşme formu & $\begin{array}{l}\text { Araştırma sonucunda, öğrencilerin okullarının bazı alanlarında hayal } \\
\text { kırıklıkları yaşadıklarını ve iki öğrencinin destek almadan başa çıma } \\
\text { stratejisi geliştirdiği belirtilmiştir. Ayrıca aile ve akranların önemli destek } \\
\text { kaynağı olduğu vurgulanmıştır. }\end{array}$ \\
\hline $\begin{array}{l}\text { Wang \& } \\
\text { Neihart, } \\
2015 \text { a }\end{array}$ & $\begin{array}{l}\text { 2f öğrencilerin akademik } \\
\text { benlik kavramı ve akademik } \\
\text { benlik yeterliliği algılarını } \\
\text { araştırmak }\end{array}$ & Nitel & $\begin{array}{l}\text { 13-15 yaşlarında } 2 \text { f olan } 6 \\
\text { Singapurlu öğrenci }\end{array}$ & Görüşme formu & $\begin{array}{l}\text { Araştırma sonucunda, } 2 \text { f öğrencilerinin akademik başarılarını güçlendiren } \\
\text { yüksek akademik benlik kavramı ve akademik öz yeterliliğe sahip } \\
\text { olabileceği ve öğretmen, ebeveyn desteğine ihtiyaç duydukları } \\
\text { belirtilmektedir. }\end{array}$ \\
\hline $\begin{array}{l}\text { Wormald } \\
\text { vd., } 2014\end{array}$ & $\begin{array}{l}\text { 2f olan bir çocuğun } \\
\text { deneyimlerini inceleyerek } \\
\text { uygun eğitim programlarına } \\
\text { olan ihtiyacı vurgulamak }\end{array}$ & Nitel & $\begin{array}{l}\text { 2f olan bir çocuk ve } \\
\text { annesi }\end{array}$ & $\begin{array}{l}\text { Yar1-yapılandırılmış } \\
\text { görüşme formu }\end{array}$ & $\begin{array}{l}\text { Araştırma sonucunda, } 2 \text { f olan öğrencinin sınıfta davranış sorunları olan biri } \\
\text { olarak algılandığı, yaşadığı zorluklar, öğretmenlerinden memnun olmadığı } \\
\text { ve eğitim siteminin iyileştirilmesine yönelik önerilerde bulunduğu } \\
\text { belirtilmektedir. }\end{array}$ \\
\hline $\begin{array}{l}\text { Mayes vd., } \\
2014\end{array}$ & $\begin{array}{l}\text { 2f öğrencilerin algılarını, } \\
\text { tutumlarını ve deneyimlerini } \\
\text { incelemek }\end{array}$ & Nitel & $\begin{array}{l}\text { 14-19 yaşlarında } 2 \mathrm{f} \text { olan } 8 \\
\text { Afrikan-Amerikalı } \\
\text { öğrenci }\end{array}$ & Görüşme formu & $\begin{array}{l}\text { Araştırma sonucunda, öğrencilerin özel eğitim durumlarının akranları, } \\
\text { öğretmenleri ve okul idarecileriyle ilişkilerini olumsuz etkilediği ve olumlu } \\
\text { benlik duygusu geliştirmek için mücadele ettikleri belirtilmektedir. }\end{array}$ \\
\hline $\begin{array}{l}\text { Wang \& } \\
\text { Neihart, } \\
2015 b\end{array}$ & $\begin{array}{l}\text { Akran, ebeveyn ve öğretmen } \\
\text { desteğinin } 2 \text { f öğrencilerin } \\
\text { akademik başarılarına } \\
\text { etkisini incelemek }\end{array}$ & Nitel & 2 f olan 6 öğrenci & $\begin{array}{l}\text { Yar1-yapılandırılmış } \\
\text { görüşme formu }\end{array}$ & $\begin{array}{l}\text { Araştırma sonucunda } 2 \mathrm{f} \text { öğrenciler, akademik başarılarını desteklemede } \\
\text { özellikle akran desteğinin önemli olduğunu ve yine ebeveynler ve öğretmen } \\
\text { desteği ile psikolojik ve davranışsal olarak olumlu etkilendiklerini } \\
\text { vurgulamışlardır. }\end{array}$ \\
\hline $\begin{array}{l}\text { Dare \& } \\
\text { Nowicki, } \\
2015\end{array}$ & $\begin{array}{l}\text { 2f çocuğa sahip ebeveynlerin } \\
\text { deneyimlerini ögrenmek }\end{array}$ & Nitel & 5 ebeveyn & Görüşme formu & $\begin{array}{l}\text { Araştırma sonucunda, ebeveynlerin çocukları için kritik rol oynadıkları ve } \\
\text { bu rolü de yerine getirebilmek için desteğe ihtiyaç duydukları } \\
\text { vurgulanmaktadır. }\end{array}$ \\
\hline $\begin{array}{l}\text { Gari vd., } \\
2015\end{array}$ & $\begin{array}{l}\text { İlkokul öğretmenlerinin 2f } \\
\text { öğrencilere yönelik } \\
\text { tutumlarını öğrenmek }\end{array}$ & Nicel & $\begin{array}{l}225 \text { Yunan ve } 158 \text { Çek } \\
\text { öğretmen }\end{array}$ & Anket & $\begin{array}{l}\text { Araştırma sonucunda öğretmenlerin } 2 \text { f olan öğrencilerin kişisel özelliklerini } \\
\text { anlamada güçlük çektikleri ve bu öğrencilerin sistematik olarak eğitim } \\
\text { almaları gerektiği vurgulanmaktadır. }\end{array}$ \\
\hline $\begin{array}{l}\text { Pereira vd., } \\
2015\end{array}$ & $\begin{array}{l}\text { 2f olan bireylere yönelik } \\
\text { ABD'de yapılan devlet } \\
\text { politikalarının incelenmesi }\end{array}$ & Nicel & $\begin{array}{l}\text { Eyalet eğitim bölümünde } \\
\text { çalışan } 42 \text { yönetici }\end{array}$ & Anket & $\begin{array}{l}\text { Araştırmanın sonucunda (a) } 2 \text { f bireylerle ilgili devlet politikasının } \\
\text { eksikliğini; (b) genel eğitim öğretmenleri, üstün zekâlılar ve özel eğitim } \\
\text { uzmanları arasında iş birliği ihtiyacı; (c) 2f için özel tanımların ve bu } \\
\text { bireylerin özelliklerinin önemi ve (d) } 2 \text { f ile ilgili girişimlere yönelik } \\
\text { modellerin var olduğunu gösterilmektedir. }\end{array}$ \\
\hline
\end{tabular}


Tablo 2 (devami)

\begin{tabular}{|c|c|c|c|c|c|}
\hline Kaynak & Araştırmanın amacı & Yöntem & Katılımcılar ve özellikleri & Veri toplama araçları & Bulgular \\
\hline $\begin{array}{l}\text { Wormald vd., } \\
2015\end{array}$ & $\begin{array}{l}\text { 2f olan bir çocuğun } \\
\text { deneyimlerini öğrenmek }\end{array}$ & Nitel & $\begin{array}{l}\text { 2f olan öğrenci, annesi ve } \\
\text { öğretmeni }\end{array}$ & Görüşme formu & $\begin{array}{l}\text { Araştırma sonucunda, } 2 \text { f olan bir çocuğun yaşadığı güçlükleri } \\
\text { belirleme ve geliştirmede zorluklar yaşadığı ve öğretmenlerin mesleki } \\
\text { gelişim ve iş birliğine ihtiyaç duyduğu belirtilmiştir. }\end{array}$ \\
\hline Mayes, 2016 & $\begin{array}{l}\text { Eğitimciler ve } \\
\text { danışmanlardan } 2 \mathrm{f} \\
\text { bireyleri desteklerken } \\
\text { karşılaştıkları deneyimler } \\
\text { ve zorluklar hakkında } \\
\text { görüş almak }\end{array}$ & Nitel & 5 eğitimci & $\begin{array}{l}\text { Yarı-yapılandırılmış } \\
\text { görüşme formu }\end{array}$ & $\begin{array}{l}\text { Araştırma sonucunda, kırsal bölgelerdeki okullarda eğitimcilere } \\
\text { yönelik çalışmaların sınırlı sayıda olduğu ve eğitimcilere destek } \\
\text { verilmesi gerektiği vurgulanmaktadır. }\end{array}$ \\
\hline $\begin{array}{l}\text { Mayes \& } \\
\text { Moore, 2016a }\end{array}$ & $\begin{array}{l}\text { Kırsal bir bölgede yaşayan } \\
\text { 2f olan ögrenci ve } \\
\text { ebeveynlerinin algılarını, } \\
\text { tutumlarını ve } \\
\text { deneyimlerini incelemek }\end{array}$ & Nitel & $\begin{array}{l}\text { 14-19 yaşlarında } 2 \mathrm{f} \text { olan } 8 \\
\text { Afrikan-Amerikalı öğrenci }\end{array}$ & Görüşme formu & $\begin{array}{l}\text { Araştırma sonucunda, } 2 \text { f öğrencilerin okul ortamında zorluk } \\
\text { yaşadıkları ve strateji geliştirmede zorlandıkları belirtilmiştir. Ayrıca } \\
\text { öğrencilerin özel eğitim kimliklerinin üstün zekâlı kimliklerinden çok } \\
\text { farklı yaşadıkları vurgulanmaktadır. }\end{array}$ \\
\hline $\begin{array}{l}\text { Lo \& Yuen, } \\
2017\end{array}$ & $\begin{array}{l}\text { 2f olan bireylerin kulland } 1 \text { ğ } \\
\text { stratejilerin belirlenmesi }\end{array}$ & Nitel & $\begin{array}{l}\text { 2f olan } 3 \text { üniversite } \\
\text { öğrencisi }\end{array}$ & $\begin{array}{l}\text { Yarı-yapılandırılmış } \\
\text { görüşme formu }\end{array}$ & $\begin{array}{l}\text { Araştırmanın sonucunda, öğrencilerin olumsuz öğrenme ortamlarına } \\
\text { karşı başa çıma stratejileri geliştirdiği ve ebeveynler ile } \\
\text { öğretmenlerin motivasyonlarını başarı için gerekli oldukları } \\
\text { vurgulanmaktadır. }\end{array}$ \\
\hline Alsamiri, 2018 & $\begin{array}{l}\text { Öğrenme güçlüğü olan } \\
\text { öğretmenlerin } 2 \text { f olan } \\
\text { bireylere yönelik } \\
\text { görüşlerini almak }\end{array}$ & Nitel & $\begin{array}{l}\text { Öğrenme güçlüğü olan } 9 \\
\text { öğretmen }\end{array}$ & Görüşme formu & $\begin{array}{l}\text { Araştırma sonucunda öğretmenler, } 2 \text { f olan bireylerin özelliklerini bir } \\
\text { alanda güçlü diğer alanlarda zayıflık olarak tanımlamaktadır. Ayrıca } \\
\text { çoğu öğretmenin bu bireyleri tanımlamakta ve özelliklerini } \\
\text { belirtmede zorluk çektiği görülmektedir. }\end{array}$ \\
\hline Park vd., 2018 & $\begin{array}{l}\text { 2f olan bir grup öğrencinin } \\
\text { ebeveynlerinin } \\
\text { deneyimlerini öğrenmek }\end{array}$ & Nitel & $\begin{array}{l}10 \text { Asya-Amerikan kökenli } \\
\text { ebeveyn }\end{array}$ & Görüşme formu & $\begin{array}{l}\text { Araştırma sonucunda ebeveynlerin çocuklarına yönelik karmaşık } \\
\text { duygular içinde oldukları ve çocuklarını destekleme konusunda } \\
\text { zorluklar yaşadıkları belirtilmektedir. }\end{array}$ \\
\hline $\begin{array}{l}\text { Ronksley-Pavia } \\
\text { vd., } 2019\end{array}$ & $\begin{array}{l}\text { 2f olan öğrencilerin } \\
\text { yaşadığ1 zorbalık } \\
\text { deneyimlerini öğrenmek }\end{array}$ & Nitel & $\begin{array}{l}\text { 2f olan } 9-16 \text { yaşlarında } 8 \\
\text { öğrenci }\end{array}$ & $\begin{array}{l}\text { Yar1-yapılandırılmış } \\
\text { görüşme formu }\end{array}$ & $\begin{array}{l}\text { Araştırma sonucunda, } 2 \mathrm{f} \text { öğrencilerin akranları ve öğretmenleri } \\
\text { tarafından zorbalığa maruz kaldıkları belirtilmektedir. }\end{array}$ \\
\hline
\end{tabular}


Tablo 3

2f Bireylere Yönelik Alanyazın Taraması Yapılan Araştırmalar

\begin{tabular}{ccc}
\hline Kaynak & \multicolumn{1}{c}{ Araştırmanın amacı } & Bulgular \\
\hline Sansom, 2015 & $\begin{array}{c}\text { 2f bireylere yönelik çalışmaların olduğu bir alanyazın taraması } \\
\text { gerçekleştirmek }\end{array}$ & $\begin{array}{c}\text { Araştırmada, 2f bireylere yönelik yapılan çalışmalar özetlenmekte ve bu bireylerin üstün } \\
\text { yeteneklerine odaklanacak şekilde eğitim verilmeleri önerilmektedir. }\end{array}$ \\
$\begin{array}{c}\text { Amran \& } \\
\text { Majid, 2019 } \\
\text { uygulamaları içeren araştırmalara yönelik alanyazın taraması } \\
\text { gerçekleştirmek }\end{array}$ & $\begin{array}{c}\text { Araştı̈rmada, 2f bireylere yönelik yapılan çalışmalar özetlenmekte ve bu bireylere yönelik aileler } \\
\text { ve ögretmenler için öğrenme stratejileri önerilmektedir. }\end{array}$ \\
\hline
\end{tabular}

Not: Makaleler yayın yılına göre geçmişten günümüze doğru sıralanmıştır.

\section{Tablo 4}

2f Bireylere Yönelik Yapılan Karşılaştırma Araştırmaları

\begin{tabular}{|c|c|c|c|c|c|}
\hline Kaynak & Araştırmanın amacı & Yöntem & Katılımc1lar ve özellikleri & Veri toplama araçları & Bulgular \\
\hline $\begin{array}{l}\text { Bell vd., } \\
2015\end{array}$ & $\begin{array}{l}\text { 2f olmaya aday öğrencileri, } \\
\text { okuma ve matematik } \\
\text { başarısında tipik gelişim } \\
\text { gösteren akranlarılyla } \\
\text { karşılaştırmak }\end{array}$ & Nicel & $\begin{array}{l}\text { 3. sınıfa devam eden } 1242 \\
\text { öğrenci }\end{array}$ & $\begin{array}{l}\text { Öğretimsel Duyarlılı̆̆ın İzlenmesi (Monitoring } \\
\text { Instructional Responsiveness) } \\
\text { Başarı Testi (Achievement Assessment. }\end{array}$ & $\begin{array}{l}\text { Araştırma sonucunda, 2f olan öğrenciler } \\
\text { hem okuma hem de matematik } \\
\text { testlerinde tipik gelişen akranlarından } \\
\text { daha düşük performans göstermişlerdir. }\end{array}$ \\
\hline $\begin{array}{l}\text { van } \\
\text { Viersen } \\
\text { vd., } 2015\end{array}$ & $\begin{array}{l}\text { 2f öğrenciler ve öğrenme } \\
\text { güçlügüü olan öğrencilere } \\
\text { yönelik okuryazarlık } \\
\text { gelişimlerine ilişkin risk ve } \\
\text { koruyucu faktörleri } \\
\text { araştırmak }\end{array}$ & Nicel & $\begin{array}{l}\text { 2. ve 4. sinıfa devam eden } \\
\text { 2f olan, öğrenme güçlüğü } \\
\text { olan ve öğrenme güçlügüü } \\
\text { riski olan } 73 \text { Hollandalı } \\
\text { çocuk }\end{array}$ & $\begin{array}{l}\text { WISC (Wechsler Intelligence Scale for Children NL) } \\
\text { Bir Dakika Testi (Eén Minuut Test) } \\
\text { PI dikte testi (PI-dictee) } \\
\text { Fonemik Analiz Testi (Fonemische Analyse Test) } \\
\text { Sürekli Adlandırma ve Okuma Testi (Continu Benoemen \& } \\
\text { Woorden Lezen) } \\
\text { Otomatik Çalışma Belleği Testi (Automated Working } \\
\text { Memory Assessment) } \\
\text { Dilin Klinik Değerlendirilmesi Testi-4 (The Clinical } \\
\text { Evaluation of Language Fundamentals-4 NL) }\end{array}$ & $\begin{array}{l}\text { Araştırma sonucunda } 2 \text { f öğrenciler, } \\
\text { okuryazarlık performanslarında öğrenme } \\
\text { güçlüğü olan ve öğrenme güçlüğü riski } \\
\text { olan akranlarından düşük performans } \\
\text { gösterdiği ve bu öğrencilerin öğrenme } \\
\text { güçlüğü durumlarını özel yetenekleri ile } \\
\text { telafi ettiklerine dair bir belirti olmadığı } \\
\text { ortaya konmuştur. }\end{array}$ \\
\hline
\end{tabular}


Tablo 4 (devami)

\begin{tabular}{|c|c|c|c|c|c|c|c|}
\hline Kaynak & Araştırmanın amacı & Yöntem & Katılimc1 & ar ve özellikleri & & Veri toplama araçları & Bulgular \\
\hline $\begin{array}{l}\text { van } \\
\text { Viersen } \\
\text { vd., } 2016\end{array}$ & $\begin{array}{l}\text { 2f olan bireylerin } \\
\text { okuryazarlik } \\
\text { performanslarını } \\
\text { belirlemek }\end{array}$ & Nicel & \multicolumn{2}{|c|}{$\begin{array}{l}\text { 2. ve 3. sinifa devam eden } \\
121 \text { ögrenci (a) öğrenme } \\
\text { güçlüğü olan grup (b) } 2 f \\
\text { olan grup (c) tipik } \\
\text { gelişen (d) üstün } \\
\text { yetenekli grup }\end{array}$} & \multicolumn{2}{|c|}{$\begin{array}{l}\text { PI dikte testi (PI-dictee) } \\
\text { Fonemik Analiz Testi (Fonemische Analyse Test) } \\
\text { Sürekli Adlandırma ve Okuma Testi (Continu Benoemen \& } \\
\text { Woorden Lezen) } \\
\text { Otomatik Çalışma Belleği Testi (Automated Working } \\
\text { Memory Assessment) } \\
\text { Dilin Klinik Değerlendirilmesi Testi-4 (The Clinical } \\
\text { Evaluation of Language Fundamentals-4 NL) }\end{array}$} & $\begin{array}{l}\text { Araştırma sonucunda, } 2 \text { f olan çocukların } \\
\text { okuryazarlık becerileri üzerinde } \\
\text { öğrenme güçlüğü olan öğrencilerden } \\
\text { daha iyi, tipik gelişen ve üstün yetenekli } \\
\text { çocuklardan daha kötü performans } \\
\text { gösterdiği belirtilmektedir. }\end{array}$ \\
\hline \multicolumn{8}{|c|}{$\begin{array}{l}\text { Tablo } 5 \\
\text { 2f Bireylere Yönelik Yapılan Müdahale Araştırmaları }\end{array}$} \\
\hline Kaynak & Araştırmanın amacı & \multicolumn{2}{|c|}{ Yöntem } & \multicolumn{2}{|c|}{ Katılımcılar ve özellikleri } & Veri toplama araçları & Bulgular \\
\hline $\begin{array}{l}\text { Al-Hroub \& } \\
\text { Whitebread, } \\
2019\end{array}$ & $\begin{array}{l}2 \text { f olan öğrenci grubunun } \\
\text { belirlenmesinde } \\
\text { dinamik } \\
\text { değerlendirmenin } \\
\text { etkililiğ }\end{array}$ & Nicel yön & & $\begin{array}{l}10-11 \text { yaşlarıno } \\
\text { çocuk }\end{array}$ & 2 f olan 30 & $\begin{array}{l}\text { WISC (Wechsler Intelligence Scale for } \\
\text { Children) } \\
\text { Dinamik Matematik Değerlendirme Testi } \\
\text { (Dynamic Assessment: The Mathematics) }\end{array}$ & $\begin{array}{l}\text { Araştırma sonucunda, dinamik } \\
\text { değerlendirmenin tüm katılımcıların } \\
\text { matematik başarılarını etkilediği } \\
\text { görülmüştür. }\end{array}$ \\
\hline $\begin{array}{l}\text { Ritchotte \& } \\
\text { Zaghlawan, } \\
2019\end{array}$ & $\begin{array}{l}\text { 2f çocukların ifade edici } \\
\text { dilini geliştirmede } \\
\text { ebeveyn koçluğuyla } \\
\text { sunulan etkileşimli } \\
\text { kitap okuma } \\
\text { müdahalesinin etkililiği }\end{array}$ & $\begin{array}{r}\text { Tek-dene } \\
\text { araştırm } \\
\text { modeli/I } \\
\text { arası çol } \\
\text { yoklama }\end{array}$ & $\begin{array}{l}\text { li } \\
\text { at1limcilar } \\
\text { nodeli }\end{array}$ & $\begin{array}{l}5-7 \text { yaş arasınd } \\
\text { çocuk }\end{array}$ & 2 f olan 4 & $\begin{array}{l}\text { Peabody Resin Kelime Testi (Peabody Picture } \\
\text { Vocabulary Test) } \\
\text { Raven'ın Renkli Aşamalı Matrisleri (Raven's } \\
\text { Coloured Progressive Matrices) } \\
\text { Özel Yetenekli Öğrencileri Tanılama Ölçekleri } \\
\text { (Scales for Identifying Gifted Students) }\end{array}$ & $\begin{array}{l}\text { Araştırma sonucunda, ebeveynlerin } \\
\text { koçluk stratejisini öğrenip } \\
\text { uygulayabildikleri ve tüm çocukların } \\
\text { ifade edici dil becerilerinde gelişme } \\
\text { olduğu ve bunu korudukları } \\
\text { gözlenmiştir. }\end{array}$ \\
\hline
\end{tabular}




\section{Tartışma ve Sonuç}

$\mathrm{Bu}$ araştırmada 2014-2019 yılları arasında ulusal ve uluslararası alanyazında $2 \mathrm{f}$ olan bireylere yönelik yayınlanan makaleler incelenmiştir. Bu kapsamda ele alınan makalelerin tamamının yurtdışında gerçekleşmiş olması oldukça dikkat çeken bir bulgudur. Türkiye'de özel yetenek ve öğrenme güçlüğü tanısı almış $2 \mathrm{f}$ bireylere yönelik yayınlanmış herhangi bir makale olmaması bu konuda bilimsel araştırmalarının gerçekleştirilmesi gerektiğini göstermektedir. $\mathrm{Bu}$ durum, Türkiye'de $2 \mathrm{f}$ olan bireylerin henüz Özel Eğitim Hizmetleri Yönetmeliği'nde yer almaması ve bu grubun diğer ülkelerle karşılaştırıldığında Türkiye'de yeni çalışılmaya başlanan bir grup olması ile açıklanabilmektedir (İlker, 2017; Milli Eğitim Bakanlığı [MEB], 2018).

Araştırma kapsamında incelenen 41 araştırmanın 13 farklı ülkede gerçekleştirildiği görülmektedir. 41 araştırmanın 23'ünün ABD'de yapıldığı görülmektedir. ABD'de özel eğitim alanında birçok çalışmanın gerçekleştiriliyor olması (Görgün \& Melekoğlu, 2016; López-Muñoz vd., 2008) göz önünde bulundurulduğunda bu durum beklenen bir durum olarak karşımıza çıkmaktadır. ABD'yi sırasıyla dört çalışma ile Avustralya, iki çalışma ile Çin, Suudi Arabistan ve Singapur takip etmektedir. Kalan ülkelerin tamamında da yalnızca bir çalışma yapılmış olması göze çarpan bir bulgudur. Buradan hareketle $2 \mathrm{f}$ olan bireylerin diğer ülkelerde de yeni çalışılmaya başlanan bir grup olduğu söylenebilmektedir. Türkiye'de ise özel öğrenme güçlüğü ve özel yeteneği olan $2 f$ bireylere yönelik yayınlanmış henüz bir makale olmaması $2 \mathrm{f}$ bireylere yönelik hazırlanacak olan eğitim programlarının eksikliği açısından düşündürücüdür. Ancak uluslararası alanyazında bu bireylere yönelik gerçekleş̧irilen araştırmalar ışığında Türkiye'de de araştırmaların sayısının artacağı beklenmektedir.

Araştırma kapsamında incelenen araştırmaların çoğunluğunun 2015 yılında yapıldığı görülmektedir. 2015 yılında yapılan araştırmaların büyük çoğunluğu ise ABD'de gerçekleştirilmiştir. En fazla araştırmanın 2015 yılında ABD'de yapılmasında Ulusal Özel Yetenekli Çocuklar Birliği (National Association for Gifted Children [NAGC]) tarafından 2013 ve 2015 yıllarında 2 f bireylere yönelik panel bildirilerinin yayınlanmasının etkili olduğu düşünülmektedir. Türkiye'de de benzer şekilde panellerin gerçekleştirilip $2 \mathrm{f}$ bireylerin özellikleri hakkında topluma bilgi verilerek farkındalık oluşturulmasının ulusal alanyazında bu bireylere yönelik gerçekleştirilecek çalışmaların sayısının artmasına katkıda bulunabileceği beklenmektedir. Araştırmaların en az yapıldığı yıllar ise sırasıyla 2017 ve 2019 yıllarıdır. Zaman ilerledikçe bu bireylere yönelik araştırmaların sayısının artacağı düşünüldüğ̈̈nde 2019 yılında bu bireylere yönelik yapılan yalnızca iki çalışma olması düşündürücü ve şaşırtıcı bir bulgu olarak karşımıza çıkmaktadır. Özel eğitimin öğrenme güçlüğü gibi nispeten yeni çalışma alanlarında araştırma sayılarının yıllar geçtikçe arttığı görülmektedir. Tıpkı öğrenme güçlüğü gibi, 2 f bireylerin de özel eğitim alanında nispeten yeni fakat önemli bir çalışma konusu olması ve 2019 yılı öncesinde yapılan araştırmaların yıllar geçtikçe artması göz önünde bulundurulduğunda, $2 \mathrm{f}$ bireylere yönelik araştırma sayılarının her yıl katlanarak artacağı beklenmektedir. Dolayısıyla 2019 yılında böyle yeni ve önemli bir çalışma alanında az sayıda araştırma gerçekleştirilmiş olması şaşırtıcıdır. Bunun yanı sıra, 2015 yılında özellikle bu bireylere yönelik bilgilendirici çalışmaların sayısının fazla olmasının yapılacak olan araştırmalara ışık tuttuğu söylenebilir.

Araştırma kapsamında incelenen makalelerin neredeyse tamamının betimsel araştırma olarak gerçekleştirildiği görülmektedir. Yalnızca üç araştırmanın karşılaştırma araştırması olduğu ve iki araştırmanın da müdahale araştırması olduğu görülmektedir (Al-Hroub \& Whitebread, 2019; Bell vd., 2015; Ritchotte \& Zaghlawan, 2019; van Viersen vd., 2015; van Viersen vd., 2016). Betimsel araştırmaların sayısının fazla olması, $2 \mathrm{f}$ bireylerin alanda oldukça yeni bir grup olmaları ve bu nedenle de onların özelliklerini, öğrenme stratejilerini ve deneyimlerini açıklama ve bu bireyler hakkında var olan durumu gözler önüne serme çabası ile açıklanabilir. Bu bulgu, Neihart'ın (2008) bulgusuyla parallelik göstermektedir. Ancak betimsel araştırmalar kadar karşılaştırma ve müdahale araştırmalarına da gereksinim duyulmaktadır. Karşılaştırma araştırmaları ile $2 \mathrm{f}$ bireylerin akademik ve sosyal gelişimlerini desteklemek amacıyla en uygun yöntem ve teknik belirlenebilir ve bu doğrultuda eğitim programı hazırlanabilir. Müdahale araştırmaları ile de $2 \mathrm{f}$ bireylerin var olan akademik performansları artırılabilir, akranlarıyla sosyal iletişimleri artırılabilir ve yaşadıkları öğrenilmiş çaresizlik ortadan kaldırılabilir. Müdahale araştırmalarının ikisinin de 2019 yılında gerçekleştirilmiş olması bu bireylerin de müdahaleye ihtiyaç duyduğunun son yıllarda farkına varıldığı şeklinde yorumlanabilmektedir. Bu bulgu oldukça dikkat çekici bir bulgu olmakla birlikte ilerleyen yıllarda bu bireylere yönelik yapılacak olan müdahale araştırmalarının sayısının artacağı düşünülmektedir.

Araştırma kapsamında incelenen betimsel araştırmaların 19 tanesini, $2 \mathrm{f}$ olan bireylerin genel öğrenme ve kişisel özellikleri hakkında bilgi veren araştırmalar oluşturmaktadır. Bu araştırmaları sırasıyla 15 araştırma ile $2 \mathrm{f}$ olan bireyler hakkında ebeveynlerden, öğretmenlerden, yöneticilerden ya da bireylerin kendisinden görüş alan araştırmalar ve iki araştırma ile de $2 \mathrm{f}$ olan bireylere yönelik alanyazın taraması olarak yapılan araştırmalar takip 
etmektedir. Özel eğitim alanında $2 \mathrm{f}$ olan bireyler küçük ve nispeten yeni çalışılmaya başlanan bir grup (Baum \& Owen, 2004) olduğu için bu bireyleri genel olarak tanımak, öğrenme ihtiyaçlarını belirleyerek bu doğrultuda eğitim planlarını oluşturmak ve zorluk yaşadıkları alanları belirlemek için betimsel araştırmalara ihtiyaç vardır. Türkiye'de de özel öğrenme güçlüğü ve özel yeteneği olan $2 \mathrm{f}$ olan bireylere yönelik gerçekleştirilen herhangi bir makalenin olmaması ve bu bireylere yönelik henüz bir eğitim planı bulunmadığından yola çıkarak Türkiye'de de bu bireylere yönelik yapılacak betimsel araştırmalara ihtiyaç olduğu söylenebilir.

Araştırma kapsamında incelenen karşılaştırma araştırmalarına bakıldığında bir araştırmada $2 \mathrm{f}$ olan bireyler akademik performans açısından tipik gelişim gösteren akranlarıyla karşılaş̧ırılmıştır (Bell vd., 2015). Araştırma sonucunda $2 \mathrm{f}$ olan bireylerin akranlarından daha düşük performans gösterdiği ortaya koyulmuştur. Diğer bir araştırmada $2 \mathrm{f}$ olan öğrenciler okuryazarlık performansları açısından, öğrenme güçlüğü olan öğrenciler, üstün yetenekli öğrenciler ve tipik gelişen akranlarıyla karşılaş̧ırılmıştır (van Viersen vd., 2016). Bu araştırma sonucunda $2 \mathrm{f}$ olan öğrencilerin öğrenme güçlüğü olan öğrencilerden daha iyi, tipik gelişen ve üstün yetenekli çocuklardan daha kötü performans gösterdiği belirlenmiştir. Son araştırmada ise $2 \mathrm{f}$ olan öğrenciler öğrenme güçlüğü olan öğrenciler ve öğrenme güçlüğü riski olan öğrenciler ile karşılaştırılmıştır (van Viersen vd., 2015). Araş̧ırma sonucunda $2 \mathrm{f}$ olan öğrencilerin öğrenme güçlüğ̈̈ durumlarını üstün yetenekleri ile telafi ettiklerine dair bir belirti gözlenmemiştir. Karşılaştırma araştırmaları sınırlı olmakla birlikte yapılan araştırmalarda 2f olan bireylerin akademik performanslarının düşük olduğu görülmektedir. Bu bulgudan hareketle $2 \mathrm{f}$ bireylerin öğrenim gereksinimlerinin eğitimciler ve aileleri tarafindan tam olarak anlaşılamadığı ve gereksinimlerine yönelik eğitim alamadıkları söylenebilir. Bu bireylerin özel yeteneklerine odaklanılmalı ve yetersizliklerinin özel yeteneklerini gölgelemesinin önüne geçilmelidir. Aynı zamanda $2 \mathrm{f}$ bireylerin öğrenilmiş çaresizliklerinin önüne geçilerek kendilerine olan güvenlerinin artırılması önemli bir noktadır. Bu bireylerin akranları, aileleri ve öğretmenleri tarafından da desteklenmesi gerektiği birçok araştırma tarafindan ortaya konulmuştur (Lo \& Yuen, 2014; Mayes vd., 2014; Wang \& Neihart, 2015b). Buradan hareketle bu bireylerin öğrenme gereksinimlerinin belirlenmesi ve bu gereksinimler doğrultusunda eğitim ve destek almalarının performanslarının artırılmasında önemli noktalardan biri olduğu söylenebilmektedir.

Araştırma kapsamında incelenen müdahale araştırmalarına bakıldığında bir araştırmanın tek-denekli araştırma modeli ile gerçekleştirildiği görülmektedir (Ritchotte \& Zaghlawan, 2019). Araştırmanın bağımsız değişkeni, erken okuryazarlık becerilerini geliştirmede son zamanlarda sıklıkla kullanılan yöntemlerden biri olan etkileşimli kitap okuma müdahalesidir. Müdahale sonucunda $2 \mathrm{f}$ olan bireylerin erken okuryazarlık becerilerinden ifade edici dil becerisinin geliştiği görülmüş̧ür. Diğer müdahale araştırmasında ise dinamik değerlendirmenin $2 \mathrm{f}$ olan çocukların matematik başarılarına etkisi incelenmiş ve araştırma sonucunda çocukların matematik başarısında artış olduğu görülmüştür (Al-Hroub \& Whitebread, 2019). Müdahale araştırmalarının sayısının oldukça sınırlı olmasına rağmen iki araştırmada da $2 \mathrm{f}$ olan çocukların performanslarında artış görülmesi olumlu bir bulgudur. $\mathrm{Bu}$ bulgudan hareketle hem Türkiye'de hem de dünyada $2 \mathrm{f}$ olan bireylere yönelik daha fazla sayıda müdahale çalışmasına ihtiyaç olduğu görülmektedir. Müdahale araştırmalarının sayısının artmasıyla birlikte bu bireylerin performanslarında da artış görülmesi ve "yapabilirim" hissiyle birlikte kendilerine olan güvenin artması beklenmektedir. Bu şekilde 2f bireylerin akranları tarafından kabulünün artmasıyla birlikte olumlu benlik geliştirmelerine yardımcı olacağı düşünülmektedir. Aynı zamanda müdahale araştırmalarının $2 \mathrm{f}$ bireylerin hem akademik hem de sosyal-duygusal gelişim alanlarına katkıda bulunması beklenmektedir.

Yapılan bu araştırma, 2014-2019 yılları arasında 2f olan bireylere yönelik hem ulusal hem de uluslararası alanyazındaki durumu ortaya koyduğu ve yapılan çalışmaları kategorilendirerek çalışmaları açıkladığı için önemlidir. Yapılan bu çalışma ile $2 \mathrm{f}$ olan bireylere yönelik Türkiye'de farkındalığın gelişmesi ve yapılacak çalışmaların sayısının artması beklenmektedir. Ayrıca incelenen çalışmalar ile $2 \mathrm{f}$ olan bireylerle çalışan kişilerin bilgi düzeylerinin artabileceği ve onlara bu bireyler hakkında yeni fikirler verebileceği düşünülmektedir. $\mathrm{Bu}$ araştırmanın iki yönden sınırlılığ bulunmaktadır. İlk olarak, bu araştırma yalnızca 2014-2019 yılları arasında hakemli dergilerde yayımlanan makalelerle sinırıdır. Araştırmada lisansüstü tezlerin yer almaması ise araştırmanın diğer sinırlılı̆̆ıdır.

Uluslararası alanyazındaki araştırmalar incelendiğinde çoğunlukla özel yetenek ve öğrenme güçlüğü tanısı alan $2 \mathrm{f}$ bireylere yönelik bilgi verici ve ailelerin ya da eğitimcilerin görüşlerine, deneyimlerine dayalı araştırmalara rastlandığı (Lo \& Yuen, 2014; Mayes vd., 2014; Wang \& Neihart, 2015b) ancak karşılaştırma ve müdahale araştırmalarının sınırlı sayıda olduğu görülmektedir. Türkiye'de ise özel yetenek ve öğrenme güçlüğü tanısı alan 2f bireylere yönelik herhangi bir makaleye rastlanmamıştı. Dolayısıyla ulusal alanyazında bu bireylerin özelliklerinin daha iyi anlaşllabilmesi ve eğitim gereksinimlerinin belirlenmesi amacıyla betimsel araştırmalara ihtiyaç olduğu düşünülmektedir. Benzer şekilde bu bireylere yönelik yapılacak karşılaştırma ve müdahale 
araştırmalarının sayısının artmasına da gereksininim bulunmaktadır. Aynı zamanda ailelere, öğretmenlere ve uzmanlara yönelik $2 \mathrm{f}$ bireyler hakkında seminerler düzenlenerek bu bireyler hakkında toplumsal farkındalığın artması sağlanabilir.

\section{Yazarların Katkı Düzeyleri}

Büşra Yılmaz Yenioğlu çalışmanın konusunu belirleme, veri toplama, verilerin analizi ve çalışmanın raporlanması görevlerinde yer almıştır. Macid Ayhan Melekoğlu çalışmanın konusunu belirleme, araştırma desenini belirleme, verilerin analizi ve çalışmanın raporlanması görevlerinde yer almıştır. 


\section{Kaynaklar}

Abramo, J. M. (2015). Gifted students with disabilities: "Twice exceptionality" in the music classroom. Music Educators Journal, 101(4), 62-69. https://doi.org/10.1177/0027432115571367

Al-Hroub, A., \& Whitebread, D. (2019). Dynamic assessment for identification of twice-exceptional learners exhibiting mathematical giftedness and specific learning disabilities. Roeper Review, 41(2), 129-142. https://doi.org/10.1080/02783193.2019.1585396

Alsamiri, Y. (2018). How learning disabilities teachers in the Kingdom of Saudi Arabia define students with giftedness and learning disabilities. Cakrawala Pendidikan, 37(3), 356-365. https://doi.org/10.21831/cp.v38i3.21566

Amend, E. R., \& Peters, D. (2015). The role of clinical psychologist: Building a comprehensive understanding of 2e students. Gifted Child Today, 38(4), 243-245. https://doi.org/10.1177/1076217515597286

Amran, H. A., \& Majid, R. A. (2019). Learning strategies for twice-exceptional students. International Journal of Special Education, 33(4), 954-976.

Assouline, S. G., \& Whiteman, C. S. (2011). Twice-exceptionality: Implications for school psychologists in the post-IDEA 2004 era. Journal of Applied School Psychology, 27(4), 380-402. https://doi.org/10.1080/15377903.2011.616576

Baker, J. A. (1995). Depression and suicidal ideation among academically talented adolescents. Gifted Child Quarterly, 39(4), 218-223. https://doi.org/10.1177/001698629503900405

Baldwin, L., Baum, S., Pereles, D., \& Hughes, C. (2015). Twice-exceptional learners: The journey toward a shared vision. Gifted Child Today, 38(4), 206-214. https://doi.org/10.1177/1076217515597277

Baldwin, L., Omdal, S. N., \& Pereles, D. (2015). Beyond stereotypes: Understanding, recognizing, and working with twice-exceptional learners. Teaching Exceptional Children, 47(4), 216-225. https://doi.org/10.1177/0040059915569361

Barnard-Brak, L., Johnsen, S. K., Pond Hannig, A., \& Wei, T. (2015). The incidence of potentially gifted students within a special education population. Roeper Review, 37(2), 74-83. https://doi.org/10.1080/02783193.2015.1008661

Baum, S. M., Olenchak, F. R., \& Owen, S. V. (1998). Gifted students with attention deficits: Fact and/or fiction? or, can we see the forest for the trees? Gifted Child Quarterly, 42(2), 96-104. https://doi.org/10.1177/001698629804200204

Baum, S., \& Owen, S. V. (1988). High ability/learning disabled students: How are they different? Gifted Child Quarterly, 32(3), 321-326. https://doi.org/10.1177/001698628803200305

Baum, S. M., \& Owen, S. V. (2004). To be gifted and learning disabled: Strategies for helping bright students with $L D, A D H D$, and more. Creative Learning Press.

Bell, S. M., Taylor, E. P., McCallum, R. S., Coles, J. T., \& Hays, E. (2015). Comparing prospective twiceexceptional students with high-performing peers on high-stakes tests of achievement. Journal for the Education of the Gifted, 38(3), 294-317. https://doi.org/10.1177/0162353215592500

Boothe, D. (2010). Twice-exceptional: Students with both gifts and challenges or disabilities. Idaho Departmant of Education. http://scholarworks.boisestate.edu/fac_books/343

Brody, L. E., \& Mills, C. J. (1997). Gifted children with learning disabilities: A review of the issues. Journal of Learning Disabilities, 30(3), 282-297. https://doi.org/10.1177/002221949703000304

Buică-Belciu, C., \& Popovici, D. V. (2014). Being twice exceptional: Gifted students with learning disabilities. Procedia-Social and Behavioral Sciences, 127, 519-523. https://doi.org/10.1016/j.sbspro.2014.03.302

Cooper, E. E., Ness, M., \& Smith, M. (2004). A case study of a child with dyslexia and spatial-temporal gifts. Gifted Child Quarterly, 48(2), 83-94 https://doi.org/10.1177/001698620404800202

Dare, L., \& Nowicki, E. A. (2015). Twice-exceptionality: Parents' perspectives on 2e identification. Roeper Review, 37(4), 208-218. https://doi.org/10.1080/02783193.2015.1077911

Eason, B. L., Smith, T. L., \& Steen, M. F. (1978). Perceptual motor programs for the gifted-handicapped. Talents and Gifts, 2(1), 10-21. https://doi.org/10.1177/016235327800200103 

YAPILAN ÇALIŞMALARIN GÖZDEN GEÇİIILMESI

Ferri, B. A., Gregg, N., \& Heggoy, S. J. (1997). Profiles of college students demonstrating learning disabilities with and without giftedness. Journal of Learning Disabilities, 30(5), 552-559. https://doi.org/10.1177/002221949703000511

Foley-Nicpon, M. (2013). Gifted child quarterly's special issue on twice-exceptionality: Progress on the path of empirical understanding. Gifted Child Quarterly, 57(4), 207-208. https://doi.org/10.1177/0016986213501195

Foley-Nicpon, M. (2015). Voices from the field: The higher education community. Gifted Child Today, 38(4), 249-251. https://doi.org/10.1177/1076217515597288

Foley-Nicpon, M., \& Assouline, S. G. (2015). Counseling considerations for the twice-exceptional client. Journal of Counseling \& Development, 93(2), 202-211. https://doi.org/10.1002/j.1556-6676.2015.00196.x

Foley-Nicpon, M., Assouline, S. G., \& Fosenburg, S. (2015). The relationship between self-concept, ability, and academic programming among twice-exceptional youth. Journal of Advanced Academics, 26(4), 256273. https://doi.org/10.1177/1932202X15603364

Fox, L. H., \& Brody, L. (1983). Models for identifying giftedness: Issues related to the learning-disabled child. In L. H. Fox, L. Brody, \& D. Tobin (Eds.), Learning disabled/gifted children: Identification and programming (pp. 101-116). University Park Press.

Gari, A., Mylonas, K., \& Portešová, S. (2015). An analysis of attitudes towards the gifted students with learning difficulties using two samples of Greek and Czech primary school teachers. Gifted Education International, 31(3), 271-286. https://doi.org/10.1177/0261429413511887

Gök, B., Baş, Ö., \& Tuncay, A. A. (2018). A twice-exceptional child-a case study. International Journal of Progressive Education, 14(2), 57-76. https://doi.org/10.29329/ijpe.2018.139.5

Görgün, B., \& Melekoğlu, M. A. (2016). Review of studies on physical activities of individuals with autism spectrum disorders (ASD). Ankara University Faculty of Educational Sciences Journal of Special Education, 17(3), 347-376. https://doi.org/10.21565/ozelegitimdergisi.268559

Gust-Brey, K., \& Cross, T. (1999). An examination of the literature base on the suicidal behaviors of gifted students. Roeper Review, 22(1), 28-35. https://doi.org/10.1080/02783199909553994

İlker, Ö. (2017). İki kere farklı: Özel yetenekli olup özel öğrenme güçlüğü yaşayan bireyler. M. A. Melekoğlu \& U. Sak (Eds.), Ö̆grenme güçlüğü ve özel yetenek [Learning disabilities and special ability] içinde (ss. 254-285). Pegem Akademi. https://doi.org/10.14527/9786053188049

İlker, Ö., \& Melekoğlu, M. A. (2017). Review of the studies on writing skills of students with specific learning disabilities in elementary education. Ankara University Faculty of Educational Sciences Journal of Special Education, 18(3), 443-469. https://doi.org/10.21565/ozelegitimdergisi.318602

Jackson, S. (1998). Bright star-Black sky: A phenomenological study of depression as a window into the psyche of the gifted adolescent. Roeper Review, 20(3), 215-221. https://doi.org/10.1080/02783199809553894

Kaplan-Sayı, A. (2018). Gifted children and attention deficit disorder/hyperactivity relation. Mersin University Journal of the Faculty of Education, 14(1), 54-68. https://doi.org/10.17860/mersinefd.320229

Karg1, E., \& Akman, B. (2003). Dikkat eksikliği hiperaktivite bozukluğuna sahip üstün yetenekli çocuklar [Gifted children with attention deficit hyperactivity disorder]. Hacettepe Üniversitesi Ĕ̈itim Fakültesi Dergisi, 24, 212-214.

Kaufmann, F., Kalbfleisch, M. L., \& Castellanos, F. X. (2000). Attention deficit disorders and gifted students: What do we really know? (Senior Scholars Series). The National Research Center on the Gifted and Talented.

Krochak, L. A., \& Ryan, T. G. (2007). The challenge of identifying gifted/learning disabled students. International Journal of Special Education, 22(3), 44-53.

Kurup, A., \& Dixit, S. (2016). Gifted with disabilities: The twice exceptional in India. Indian Educational Review, $54(2), 7-25$.

Lee, C. W., \& Ritchotte, J. A. (2018). Seeing and supporting twice-exceptional learners. The Educational Forum, 82(1), 68-84. https://doi.org/10.1080/00131725.2018.1379580 
Lo, C. C., \& Yuen, M. (2014). Coping strategies and perceived sources of support among gifted students with specific learning disabilities: Three exploratory case studies in Hong Kong. Gifted and Talented International, 29(1-2), 125-136. https://doi.org/10.1080/15332276.2014.11678435

Lo, C. C., \& Yuen, M. (2017). Succeeding against the odds: Observations on coping by three intellectually very able university students with specific learning difficulties in Hong Kong. Gifted Education International, 33(3), 232-247. https://doi.org/10.1177/0261429415585407

López-Muñoz, F., Alamo, C., Quintero-Gutiérrez, F. J., \& García-García, P. (2008). A bibliometric study of international scientific productivity in attention deficit hyperactivity disorder covering the period 19802005. European Child \& Adolescent Psychiatry, 17(6), 381-391. https://doi.org/10.1007/s00787-008$\underline{0680-1}$

Macfarlane, S. (2000). Gifted children with learning disabilities: A paradox for parents. Retrieved from http://www.tki.org.nz/r/gifted/handbook/related/disabilities_e.php

Maddocks, D. L. (2018). The identification of students who are gifted and have a learning disability: A comparison of different diagnostic criteria. Gifted Child Quarterly, 62(2), 175-192. https://doi.org/10.1177/0016986217752096

Maker, C. (1977). Providing programs for the gifted handicapped. Council for Exceptional Children.

Mayes, R. D. (2016). Educators' perceptions of twice exceptional African-American males. Journal of African American Males in Education, 7(1), 20-34.

Mayes, R. D., \& Moore, J. L. (2016a). Adversity and pitfalls of twice-exceptional urban learners. Journal of Advanced Academics, 27(3), 167-189. https://doi.org/10.1177/1932202X16649930

Mayes, R. D., \& Moore, J. L. (2016b). The intersection of race, disability, and giftedness: Understanding the education needs of twice-exceptional, African-American students. Gifted Child Today, 39(2), 98-104. https://doi.org/10.1177/1076217516628570

Mayes, R. D., Hines, E. M., \& Harris, P. C. (2014). Working with twice-exceptional African-American students: Information for school counselors. Interdisciplinary Journal of Teaching and Learning, 4(2), 125-139.

Melekoğlu, M. A., Çakıroğlu, O., \& Malmgren, K. W. (2009). Special education in Turkey. International Journal of Inclusive Education, 13(3), 287-298. https://doi.org/10.1080/13603110701747769

Milli Eğitim Bakanlığı [Ministry of National Education]. (2018). Özel Eğitim Hizmetleri Yönetmeliği [Special Education Services Regulation]. T.C Resmi Gazete (30471), 07 Temmuz 2018.

Mohammed, A. (2018). Twice-exceptionality in the Kingdom of Saudi Arabia: Policy recommendations for advances in special education. International Journal of Special Education, 33(2), 397-415.

Moon, S. M., Zentall, S. S., Grskovic, J. A., Hall, A., \& Stormont, M. (2001). Emotional and social characteristics of boys with AD/HD and giftedness: A comparative case study. Journal for the Education of the Gifted, 24(3), 207-247. https://doi.org/10.1177/016235320102400302

Moon, S., \& Reis, S. (2004). Acceleration and twice-exceptional students. In N. Colangelo, S. Assouline, \& M. Gross (Eds.), A nation deceived: How schools hold back America's brightest students (pp. 109-119). The Belin Blank Center Gifted Education and Talent Development.

Morrison, W. F. (2001). Emotional/behavioral disabilities and gifted and talented behaviors: Paradoxical or semantic differences in characteristics? Psychology in the Schools, 38(5), 425-431. https://doi.org/10.1002/pits.1031

National Association for Gifted Children. (2015). Today's topic: The exceptionality of being twice exceptional. Retrieved from https://www.nagc.org/sites/default/files/CHP_sept-2015.pdf

Neihart, M. (2008). Identifying and providing services to twice exceptional children. In S. Pfeiffer (Ed.), Handbook of Giftedness in Children (pp. 115-137). Springer.

Neihart, M., \& Poon, K. K. (2009). Gifted children with autism spectrum disorders. Prufrock Press.

Newman, T. M., \& Sternberg, R. J. (Eds.) (2004). Students with both gifts and learning disabilities: Identification, assessment, and outcomes. Kluwer/Plenum.

Nielsen, M. E. (2002). Gifted students with learning disabilities: Recommendations for identification and programming. Exceptionality, 10(2), 93-111. https://doi.org/10.1207/S15327035EX1002_4 
Nielsen, M. E., Higgins, L. D., Wilkinson, S. C., \& Webb, K. W. (1994). Helping twice-exceptional students to succeed in high school: A program description. The Journal of Secondary Gifted Education, 5(3), 35-39.

O'Sullivan, M., Robb, N., Howell, S., Marshall, K., \& Goodman, L. (2017). Designing inclusive learning for twice exceptional students in Minecraft. International Journal of E-Learning \& Distance Education, 32(2), 125.

Ömür. N. (2019). Üstün zekâlı otizm spektrum bozukluğu (OSB) olan çocukların özellikleri, davranışları ve eğitim gereksinimlerinin temellendirilmiş teoriyle belirlenmesi [Exploration of characteristics, behaviors and educational needs of children with gifted autism spectrum disorder through grounded theory] (Tez Numarasi: 587370) [Yüksek lisans tezi, Anadolu Üniversitesi]. Yüksek Öğretim Kurulu Ulusal Tez Merkezi.

Park, S., Foley-Nicpon, M., Choate, A., \& Bolenbaugh, M. (2018). "Nothing Fits Exactly": Experiences of AsianAmerican parents of twice-exceptional children. Gifted Child Quarterly, 62(3), 306-319. https://doi.org/10.1177/0016986218758442

Pereira, N., Knotts, J. D., \& Roberts, J. L. (2015). Current status of twice-exceptional students: A look at legislation and policy in the United States. Gifted and Talented International, 30(1-2), 122-134. https://doi.org/10.1080/15332276.2015.1137463

Reis, S. M., Baum, S. M., \& Burke, E. (2014). An operational definition of twice-exceptional learners: Implications and applications. Gifted Child Quarterly, 58(3), 217-230. https://doi.org/10.1177/0016986214534976

Reis, S. M., McGuire, J. M., \& Neu, T. W. (2000). Compensation strategies used by high-ability students with learning disabilities who succeed in college. Gifted Child Quarterly, 44(2), 123-134. https://doi.org/10.1177/001698620004400205

Ritchotte, J. A., \& Zaghlawan, H. Y. (2019). Coaching parents to use higher level questioning with their twiceexceptional children. Gifted Child Quarterly, 63(2), 86-101. https://doi.org/10.1177/0016986218817042

Ronksley-Pavia, M. (2015). A model of twice-exceptionality: Explaining and defining the apparent paradoxical combination of disability and giftedness in childhood. Journal for the Education of the Gifted, 38(3), 318340. https://doi.org/10.1177/0162353215592499

Ronksley-Pavia, M., Grootenboer, P., \& Pendergast, D. (2019). Bullying and the unique experiences of twice exceptional learners: Student perspective narratives. Gifted Child Today, 42(1), 19-35. https://doi.org/10.1177/1076217518804856

Sansom, S. (2015). Gifted students with learning disabilities: A current review of the literature. Acta Scientiae et Intellectus, 1(1), 5-17.

Satterley, D. (2015). Special education coordinator: Learning lessons from all our students. Gifted Child Today, 38(4), 237-238. https://doi.org/10.1177/1076217515597284

Shaywitz, S. E., Holahan, J. M., Freudenheim, D. A., Fletcher, J. M., Makuch, R. W., \& Shaywitz, B. A. (2001). Heterogeneity within the gifted: Higher IQ boys exhibit behaviors resembling boys with learning disabilities. Gifted Child Quarterly, 45(1), 16-23. https://doi.org/10.1177/001698620104500103

Silverman, L. K. (2009). The measurement of giftedness. In L. V. Shavinina (Ed.), International handbook on giftedness (pp. 947-970). Springer.

Stewart, W. (2003). The gifted and learning disabled student: Teaching methodology that works. In D. Montgomery (Ed.), Gifted \& talented children with special educational needs: Double exceptionality (pp. 25-41). David Fulton.

Trail, B. (2011). Twice-exceptional gifted children: Understanding, teaching, and counseling gifted students. Purfrock Press.

van Viersen, S., de Bree, E. H., Kroesbergen, E. H., Slot, E. M., \& de Jong, P. F. (2015). Risk and protective factors in gifted children with dyslexia. Annals of Dyslexia, 65(3), 178-198. https://doi.org/10.1007/s11881-015-0106-y

van Viersen, S., Kroesbergen, E. H., Slot, E. M., \& de Bree, E. H. (2016). High reading skills mask dyslexia in gifted children. Journal of Learning Disabilities, 49(2), 189-199. https://doi.org/10.1177/0022219414538517

Vespi, L., \& Yewchuk, C. (1992). A phenomenological study of the social/emotional characteristics of gifted learning disabled children. Journal for the Education of the Gifted, 16(1), 55-72. https://doi.org/10.1177/016235329201600107 

YAPILAN ÇALIŞMALARIN GÖZDEN GEÇIRILILMESI

Wang, C. W., \& Neihart, M. (2015a). Academic self-concept and academic self-efficacy: Self-beliefs enable academic achievement of twice-exceptional students. Roeper Review, 37(2), 63-73. https://doi.org/10.1080/02783193.2015.1008660

Wang, C. W., \& Neihart, M. (2015b). How do supports from parents, teachers, and peers influence academic achievement of twice-exceptional students. Gifted Child Today, 38(3), 148-159. https://doi.org/10.1177/1076217515583742

Webb, J. T., \& Latimer, D. (1993). ERIC Digest ADHD and children who are gifted. Exceptional Children, 60(2), 183184. https://doi.org/10.1177/001440299306000213

Whitmore, J. R., \& Maker, C. J. (1985). Intellectual giftedness in disabled persons. Aspen Publishers.

Willard-Holt, C. (1998). Academic and personality characteristics of gifted students with cerebral palsy: A multiple case study. Exceptional Children, 65, 37-50. https://doi.org/10.1177/001440299806500103

Wormald, C. M., Vialle, W., \& Rogers, K. B. (2014). Young and misunderstood in the education system: A case study of giftedness and specific learning disabilities. Australasian Journal of Gifted Education, 23(2), 16-28.

Wormald, C., Rogers, K. B., \& Vialle, W. (2015). A case study of giftedness and specific learning disabilities: Bridging the two exceptionalities. Roeper Review, 37(3), 124-138. https://doi.org/10.1080/02783193.2015.1047547

Yssel, N., Adams, C., Clarke, L. S., \& Jones, R. (2014). Applying an RTI model for students with learning disabilities who are gifted. Teaching Exceptional Children, 46(3), 42-52. https://doi.org/10.1177/004005991404600305

Zentall, S. S., Moon, S. M., Hall, A. M., \& Grskovic, J. A. (2001). Learning and motivational characteristics of boys with AD/HD and/or giftedness. Exceptional Children, 67(4), 499-519. https://doi.org/10.1177/001440290106700405 


\section{Ankara University Faculty of \\ Educational Sciences Journal of \\ Special Education}

$2021,22(4), 999-1024$
REVIEW

Recieved Date: 28.02 .20

Accepted Date: 15.11 .20

OnlineFirst: 29.11 .20

\title{
Review of Studies for Twice Exceptional Individuals with Learning Disabilities and Giftedness
}

\author{
Büşra Yılmaz-Yenioğlu iD 1
}

\author{
Macid Ayhan Melekoğlu iD2
}

\begin{abstract}
Introduction: The twice exceptional (2e) individuals demonstrate superior ability in one or more areas, and also have one or more disabilities. The term $2 \mathrm{e}$ includes having specific learning disabilities, attention deficit and hyperactivity disorder (ADHD), autism spectrum disorder (ASD) social emotional development disorder in addition to having a special ability.

Method: The aim of this research is to make a descriptive analysis by examining the national and international studies conducted between 2014-2019 about 2e individuals. The keywords were searched in databases and 41 articles were examined.

Findings: It is emphasized that $2 \mathrm{e}$ individuals are new group within the special education area and more research is needed. The majority of the articles examined were carried out as descriptive research and the number of intervention studies was quite limited.
\end{abstract}

Discussion: The findings were discussed and an overview of the articles was presented.

Keywords: Twice exceptional, 2e, specific learning disabilities, gifted, descriptive analysis.

To cite: Y1lmaz-Yenioğlu, B., \& Melekoğlu, M. A. (2021). Review of studies for twice exceptional individuals with learning disabilities and giftedness. Ankara University Faculty of Educational Sciences Journal of Special Education, 22(4), 999-1024. https://doi.org/10.21565/ozelegitimdergisi.696065

${ }^{1}$ Corresponding Author: Res. Assist., Ankara University, E-mail: byyenioglu@ ankara.edu.tr, https://orcid.org/0000-00025150-5944

${ }^{2}$ Prof., Eskişehir Osmangazi University, E-mail: macidayhan@gmail.com, https://orcid.org/0000-0002-9933-5331 


\section{Introduction}

The twice exceptional (2e) individuals demonstrate superior ability in one or more areas, and also have one or more disabilities. (Neihart, 2008; Ömür, 2019). Since 1970s, the studies have been carried out for 2e individuals. (Neihart, 2008; Sansom, 2015). 2e individuals were first mentioned in the book "Providing Programs for the Gifted Handicapped" published in 1977 (Assouline \& Whiteman, 2011). The first studies for these individuals were carried out in 1981 by John Hopkins University (Buică-Belciu \& Popovici, 2014). It was the first time that James J. Gallegher used the term differently in the literature in 2004 (Boothe, 2010).

Within the scope of special education, the specific learning disabilities are commonly observed (Melekoğlu et al., 2009). The most important characteristics of individuals with specific learning disabilities are that they have normal and above normal intelligence capacity. But they have significant difficulty in academic skills, especially in reading and writing (İlker \& Melekoğlu, 2017). Some of them may also appear as specially gifted individuals. 2e individuals are defined as being gifted in one or more of the areas such as academic skills, leadership, creativity, and visual arts, other than literacy and mathematics. On the other hand, 2e individuals have difficulties in one or more of certain areas such as reading, writing and mathematics (Boothe, 2010). 2e individuals are widely known as students with learning disabilities and special abilities (Buică-Belciu \& Popovici, 2014; Neihart, 2008; Nielsen, 2002). It is difficult to point out the general characteristics for these individuals due to individual differences (Buică-Belciu \& Popovici, 2014; Foley-Nicpon, 2013; Nielsen, 2002). 2e individuals can be difficult to identify as they exhibit both learning disabilities and special abilities. While learning difficulties of these students may overshadow their special abilities in some cases, their gift may prevent their learning difficulties (Boothe, 2010; Trail, 2011). Typically, 2e individuals fall into one of the following three categories (Amran \& Majid, 2019; Buică-Belciu \& Popovici, 2014):

Individuals who are identified as gifted and are not identified with learning disabilities. The inadequacies of $2 \mathrm{e}$ individuals in this group are masked by the individual's special abilities. They are successful in primary school and can benefit from a special talent program. However, they may have problems as their expectations and responsibilities increase. They are often considered unsuccessful due to poor self-concept, lack of motivation or because they are considered lazy (İlker, 2017).

Individuals diagnosed with learning disabilities but not identified as gifted. The special abilities of the 2e individuals in this group are overshadowed by their shortcomings. These individuals are rarely diagnosed with special skills as their potential is not noticed and are referred to special education services.

Both learning disabilities and gift are not identified. The $2 \mathrm{e}$ individuals in this group are considered as average. Therefore, they are not recognized as disabled or especially talented. There is no difference between these individuals' intelligence scores and performances. Learning disabilities and special ability of individuals in this group shadow each other. Therefore, they are not recognized as having a disability, gift or talent (Amran \& Majid, 2019; Buică-Belciu \& Popovici, 2014).

2e individuals are considered as productive, imaginative, specialized in certain areas, having different interests. They show superior success in areas such as science and geometry despite experiencing learning difficulties (İlker, 2017; Macfarlane, 2000; Stewart, 2003). They receive visual and auditory information quickly and have good metacognitive, reasoning and problem solving skills (Buică-Belciu \& Popovici, 2014; Stewart, 2003). They may also have some weaknesses (Sansom, 2015). These individuals may not prefer to participate in class activities as they mostly perform below the average. They have difficulties in short and long term memory, are not able to follow instructions, experience significant reading and writing problems including reading comprehension (Baldwin, Baum, et al., 2015; Foley-Nicpon, 2015; Nielsen, 2002). They may also experience social and emotional problems.

In the absence of the high performance expected of them, 2e individuals can become angry and develop a sense of hatred towards the school. They may have low motivation and experience difficulties in communicating with their peers due to learned helplessness (Sansom, 2015). Furthermore, in case of experiencing failure, they can hold others responsible for their failures (Buică-Belciu \& Popovici, 2014; Macfarlane, 2000; Sansom, 2015).

In a study conducted by Amran and Majid in 2019, a literature review was conducted for research involving learning strategies and interventions for $2 \mathrm{e}$ individuals. The authors reviewed and summarized 44 studies in which interventions for these individuals were carried out between 2000 and 2018. The authors stated that $2 \mathrm{e}$ individuals needed to focus on their strengths and receive the support of teachers, families and peers in order to 
achieve effective intervention. Karg1 and Akman (2003) revealed the academic, social-emotional development profiles of 2e individuals with special skills and ADHD. The authors emphasized that the characteristics of $2 \mathrm{e}$ individuals including their weaknesses and strengths needed to be identified, and that a supportive education environment should be created in line with the needs of these individuals.

2e individuals are defined as a fairly new group within the field of special education. Therefore, the characteristics of these individuals should be known and they need to receive education according to their needs. The number of studies carried out for $2 \mathrm{e}$ individuals is limited in national and international literature. Also there is no article published about gifted individuals with specific learning disabilities in Turkey. Due to aforementioned reasons, this research has been conducted. The aim of this study is to examine the current national and international studies on gifted individuals with specific learning disabilities conducted between 2014-2019 and to evaluate these studies in terms of their different features. The term $2 \mathrm{e}$ is used to indicate gifted individuals with specific learning disabilities in this study.

\section{Method}

\section{Research Model}

This research reviewed the studies that included twice exceptional (2e) individuals. Document analysis was used. The data were obtained from electronic resources. Descriptive analysis was used for data analysis. Electronic databases were scanned as a data collection source.

\section{Literature Search}

The national databases that included TÜBİTAK ULAKBIM and DergiPark were searched by utilizing the keywords "twice exceptional", "gifted and specific learning disabilities" and "talented and learning disability". The search results yielded an article published in Turkey. However, since the term 2e in this article is used for a situation where special ability and attention deficit/hyperactivity disorder are seen together, this article was not included in the scope of this study (Kaplan-Say1, 2018). The international databases included SAGE, Proquest and EbscoHost databases. The following keywords were used: "Twice exceptional", "gifted with learning disabilities" and "twice exceptional students". 172 articles with the keyword "twice exceptional", three articles with the keyword "gifted with learning disabilities" and 86 articles with the keyword "twice exceptional students" were found in the SAGE. 142 articles with the keyword "twice exceptional", 14 articles with the keyword "gifted with learning disabilities" and 71 articles with the keyword "twice exceptional students" were reached in the Proquest. 146 articles with the keyword "twice exceptional", one article with the keyword "gifted with learning disabilities" and 22 articles with the keyword "twice exceptional students" were reached in the EbscoHost.

\section{Inclusion and Exclusion Criteria}

Inclusion and exclusion criteria were determined. The inclusion criteria were in the following: (a) The studies were conducted between 2014-2019, (b) 2e individuals were diagnosed with learning disability and giftedness, (c) the study was a research article published in a refereed journal. The exclusion criteria were in the following: (a) The studies were published before 2014, (b) the 2e individuals had a different diagnosis excluding learning disabilities. 41 articles met the inclusion criteria. An overview of the articles was presented in terms of (a) the distribution according to national and international literature, (b) location, (c) publication year and (d) type of the study. The articles were analyzed in terms of the purpose, method, participant characteristics and data collection tools. In order to ensure the reliability, an expert in the field of special education performed electronic search in the same databases mentioned above using the same keywords. The same articles were identified by the expert. Coding reliability was calculated as $100 \%$. The authors first read the articles independent of each other and categorized them. 95\% consistency was seen in the categorization of the articles. Then they met together and discussed the identified categories and agreed to utilize the corresponding categories.

The articles were numbered in the analysis. The researchers identified three categories by examining the articles. These were in the following: (a) Descriptive studies conducted on 2e individuals, (b) comparison studies conducted on 2e individuals, and (c) intervention studies conducted on 2e individuals. Descriptive studies were also divided into three groups that provided information about the personal and learning characteristics of $2 \mathrm{e}$ individuals, that included participants such as parents, teachers, school principals, or 2e individuals themselves who gave information about $2 \mathrm{e}$, and that presented a review of previous studies about these individuals. The numbered articles were shown in appropriate categories. 


\section{Results}

When the articles were analyzed according to the national and international publication status, all the articles were conducted in the international literature. When the articles were analyzed according to the countries in which they were published, the articles were published in 13 different countries. Twenty-three of the examined articles were conducted in the United States of America (USA) and four in Australia. These countries were followed by two articles in China, Saudi Arabia, Singapore. One article was found in the Netherlands, Canada, Malaysia, India, Romania, Ireland, Czech Republic, Greece and Jordan. When the articles were analyzed in terms of the year of publication, the results indicated that most of the articles were published in $2015(n=19)$. Seven articles were published in 2018, six in 2014, four in 2016, three in 2019 and two in 2017. When the articles were analyzed by research types, the results showed that the majority of the articles were descriptive studies. Thirty-six articles were descriptive, three articles were comparison and two articles were based on intervention.

Within the context of descriptive research, there were 19 articles that provided information about the personal and learning characteristics and learning strategies for $2 \mathrm{e}$ individuals, explanations on how these strategies should be implemented, and comments on the policies and legal rights of these individuals. There were 15 articles that included opinions from parents, teachers and administrators about 2e individuals or individuals themselves, and recommendations for these individuals in line with these opinions. There were two articles that conducted literature review on $2 \mathrm{e}$ individuals. There were three articles that compared $2 \mathrm{e}$ individuals with their peers who only had learning disabilities, peers who were diagnosed only as gifted or peers with typical development in terms of academic and developmental profiles. Finally, there were two articles that examined the effectiveness of intervention practices to increase the academic success of $2 \mathrm{e}$ individuals.

\section{Discussion}

All of the studies focused on this topic were carried out outside of Turkey. The lack of studies about gifted individuals with learning disabilities shows that there is a need on a national basis. 2e individuals are not officially mentioned in the Special Education Services Regulation, and this group of individuals is not known extensively in Turkey compared to other countries in the world (İlker, 2017; Ministry of National Education, 2018).

Forty-one studies were carried out in 13 different countries. Considering the fact that many studies in the field of special education were conducted in the USA (Görgün \& Melekoğlu, 2016; López-Muñoz et al., 2008), this was expected. The USA was followed by Australia with four studies, China, Saudi Arabia and Singapore with two studies. Only one study was conducted in all the remaining countries. This showed that the remaining countries had just started to carry out research on 2e individuals. In Turkey, there is no article published on this subject. There is a need for further research so that appropriate training programs will be prepared for these individuals.

The majority of the studies was carried out in 2015. The publication of panel statements for 2e individuals in 2013 and 2015 by the National Association for Gifted Children (NAGC) might have had impact on the number of studies in the USA in 2015. The least number of studies were published in 2017 and 2019, respectively. Considering that the number of studies about these individuals is expected to increase as time progresses, finding only two studies in 2019 is a surprising result. Furthermore, the high number of informative studies in 2015 may shed light on the personal and learning characteristics of $2 \mathrm{e}$ individuals among future studies.

Almost all of the articles were carried out as descriptive research. Only three and two studies were based on comparison and intervention, respectively (Al-Hroub \& Whitebread, 2019; Bell et al., 2015; Ritchotte \& Zaghlawan, 2019; van Viersen et al., 2016; van Viersen et al., 2015). The high number of descriptive studies can be explained by the fact that $2 \mathrm{e}$ individuals form a fairly new group and therefore those studies explain 2e individuals' characteristics, learning strategies and experiences, and reveal the current situation about these individuals. This finding is in line with a previous study (Neihart, 2008). The limited number of intervention studies creates the need for more studies.

Furthermore, 19 of the descriptive studies provided information about the learning and personal characteristics of $2 \mathrm{e}$ individuals. These studies were followed by 15 studies on opinions of parents, teachers, administrators or individuals themselves about $2 \mathrm{e}$ individuals, and 2 literature review studies on $2 \mathrm{e}$ individuals. As these individuals form a small group in the field of special education (Baum \& Owen, 2004), descriptive research is needed to identify the learning needs of these individuals, to prepare education plans according to needs and to determine the areas where they experience difficulties. 
The findings indicated that the $2 \mathrm{e}$ individuals were compared with their peers who showed typical development in terms of academic performance in one study (Bell et al., 2015). 2e individuals showed lower performance compared to their peers. In another study, 2e students were compared with students with dyslexia, gifted students and typically-developing peers (van Viersen et al., 2016). The findings indicated that 2e students showed higher performance compared to students with dyslexia but they showed lower performance compared to typically developing peers and gifted children. In the last study, 2e students were compared with students with dyslexia and those at risk for dyslexia (van Viersen et al., 2015). As a result of the research, there was no indication that $2 \mathrm{e}$ students compensated learning disabilities with their special abilities. Despite the limited number of comparison studies, the academic performance of $2 \mathrm{e}$ individuals was lower than expected. The learning needs of these individuals should be identified and they should receive education in line with these needs.

One study was designed with a single-subject research model (Ritchotte \& Zaghlawan, 2019). The independent variable was interactive book reading intervention, one of the frequently used methods in developing early literacy skills in recent years. As a result of the intervention, the expressive language results improved for $2 \mathrm{e}$ individuals (one of the critical early literacy skills). In another study, the effect of dynamic assessment on mathematics achievement of $2 \mathrm{e}$ children was examined. The results indicated that there was an increase in children's mathematics achievement (Al-Hroub \& Whitebread, 2019). Although the number of intervention studies is limited, it is a remarkable finding to observe progress in the performances of $2 \mathrm{e}$ children. Based on these findings, more intervention studies need to be conducted.

As a result, this study presented national and international literature for $2 \mathrm{e}$ individuals between 2014 and 2019 , categorized the published studies, and explained previous studies in detail. It is expected that the awareness about $2 \mathrm{e}$ individuals will be raised in Turkey and the number of studies will increase on 2e individuals following the current study. In addition, it is expected that the knowledge level of people working with $2 \mathrm{e}$ individuals will increase and the results of the study will provide new ideas about these individuals for the stakeholders. This research has two limitations. First of all, the publication year of the articles was limited between 2014 and 2019 in order to examine the current studies. Therefore, few articles were reached between these years. The absence of theses is the other limitation.

The studies in the international literature included the opinions and experiences of families or teachers through which are information regarding 2e individuals was gathered (Lo \& Yuen, 2014; Mayes et al., 2014; Wang \& Neihart, 2015b), but comparison and intervention studies were limited. In Turkey, no study was found regarding $2 \mathrm{e}$ individuals with learning disabilities and special abilities. Therefore, descriptive research is needed to better understand the characteristics of these individuals and to identify their educational needs on a national basis. Similarly, there is a need for comparison and intervention studies regarding these individuals. At the same time, seminars about these individuals can be organized for families, teachers and experts, and social awareness can be increased.

\section{Author's Contributions}

Büssra Yılmaz-Yenioğlu took part in determining the subject of the manuscript, data collection, data analysis and reporting of the study. Macid Ayhan Melekoğlu took part in determining the subject of the manuscript, determining research design, data analysis and reporting of the study. 